\title{
Dimethyl sulfide acts as eat-me signal during microbial predator-prey interactions in the ocean
}

\section{Adva Shemi}

The Weizmann Institute of Science

Uria Alcolombri

ETH Zurich https://orcid.org/0000-0003-3561-5091

\section{Daniella Schatz}

Weizmann Institute of Science https://orcid.org/0000-0003-2740-8391

\section{Viviana Farstey}

The Interuniversity Institute for Marine Sciences

\section{Ron Rotkopf}

Weizmann Institute of Science https://orcid.org/0000-0001-9503-7348

\section{Shifra Ben-Dor}

Weizmann Institute of Science https://orcid.org/0000-0001-9604-1939

\section{Miguel Frada}

The Interuniversity Institute of Eilat https://orcid.org/0000-0001-8287-0795

\section{Dan Tawfik}

Weizmann Institute of Science https://orcid.org/0000-0002-5914-8240

Assaf Vardi ( $\square$ assaf.vardi@weizmann.ac.il )

Weizmann Institute of Science https://orcid.org/0000-0002-7079-0234

\section{Research Article}

Keywords: Oceanic Carbon and Sulfur Cycles, Bloom Events, Chemoattraction, Prey Cells, Emiliania huxleyi, Oxyrrhis marina

Posted Date: January 22nd, 2021

DOl: https://doi.org/10.21203/rs.3.rs-139243/v1

License: (c) (i) This work is licensed under a Creative Commons Attribution 4.0 International License. Read Full License

Version of Record: A version of this preprint was published at Nature Microbiology on October 25th, 2021. See the published version at https://doi.org/10.1038/s41564-021-00971-3. 



\section{Dimethyl sulfide acts as eat-me signal during microbial predator-prey interactions in the ocean}

Adva Shemi ${ }^{1}$, Uria Alcolombri ${ }^{1,2}$, Daniella Schatz ${ }^{1}$, Viviana Farstey ${ }^{3}$, Ron Rotkopf ${ }^{4}$, Shifra Ben-Dor ${ }^{4}$, Miguel J. Frada ${ }^{3,5}$, Dan S. Tawfik ${ }^{6}$, Assaf Vardi ${ }^{1 *}$

${ }^{1}$ Department of Plant and Environmental Sciences, Weizmann Institute of Science, Rehovot 7610001, Israel.

${ }^{2}$ Institute of Environmental Engineering, Department of Civil, Environmental and Geomatic Engineering, ETH Zurich, Zurich, Switzerland.

${ }^{3}$ The Interuniversity Institute for Marine Sciences, Eilat 8810302, Israel.

${ }^{4}$ Department of Life Sciences Core Facilities, Weizmann Institute of Science, Rehovot 7610001, Israel.

${ }^{5}$ Department of Ecology, Evolution and Behavior, Alexander Silberman Institute of Life Sciences, Hebrew University of Jerusalem, Jerusalem 91904, Israel.

${ }^{6}$ Department of Biomolecular Sciences, Weizmann Institute of Science, 7610001 Rehovot, Israel.

*Corresponding author. E-mail: assaf.vardi@weizmann.ac.il (A.V.)

\section{Summary}

Phytoplankton are key components of the oceanic carbon and sulfur cycles ${ }^{1}$. During bloom events, some species can emit massive amounts of the organosulfur volatile dimethyl sulfide (DMS) to the atmosphere, where it can modulate aerosol formation and affect climate $^{2,3}$. In aquatic environments, DMS plays an important role as a chemical signal mediating diverse trophic-level interactions. Yet its role in microbial predator-prey interactions remains elusive with contradicting evidence for its role in algal chemical defense and in grazer's chemoattraction to prey cells ${ }^{4-6}$. Here, we investigated the signaling role of DMS during zooplankton-algae interactions by genetic and biochemical manipulation of the algal DMS-generating enzyme (Dimethylsulfoniopropionate lyase, DL) from the bloom-forming alga Emiliania huxleyi ${ }^{7}$. We inhibited DL activity in live $E$. huxleyi cells by the novel DL-inhibitor 2-bromo-3-(dimethylsulfonio)-propionate (BrDMSP) ${ }^{8}$, and overexpressed DL in the model diatom Thalassiosira pseudonana. We showed that algal DL activity did not serve as anti-grazing chemical defense, and paradoxically enhanced grazing by the model microzooplankton Oxyrrhis marina and other micro- and mesozooplankton, including ciliates and copepods. Consumption of algal prey with induced DL activity also promoted $O$. marina's growth. Overall, our results demonstrate that DMS-mediated herbivory may be ecologically important and prevalent 
during prey-predator dynamics in oceanic ecosystems. The role of algal DMS acting as eatme signal to grazers revealed here raises fundamental questions regarding the retention of its biosynthetic enzyme through the evolution of dominant bloom-forming phytoplankton in the ocean.

41

The ocean is the main source of atmospheric dimethyl sulfide (DMS), with an estimated flux of 13 to $37 \mathrm{Tg} \mathrm{S}$ year $^{-1} 1,9$. The gaseous DMS is a precursor of sulfate aerosols, mediating cloud condensation and promoting a cooling effect on Earth's climate ${ }^{1,2,10}$. DMS is produced by marine phytoplankton through cleavage of the zwitterionic organosulfur compound dimethylsulfoniopropionate (DMSP) by the DMSP lyase (DL) enzyme ${ }^{11-13}$. In phytoplankton, DMSP was proposed to act as an intracellular osmoprotectant, antioxidant and energy dissipation factor ${ }^{14-16}$. In addition, both DMSP and DMS were also shown to act as infochemicals (chemical cues that facilitate communication), mediating virulence or symbiosis by bacteria (for DMSP) ${ }^{17,18}$, and promoting prey-predator interaction and parasite infection (for DMS) ${ }^{19}$. Notably, marine predators including invertebrates, sea birds and whales, can sense DMS and track it to find areas of high productivity ${ }^{20-24}$. Although DMS is highly produced via DMSP lyase (DL) in grazed algal cells ${ }^{25}$, its signaling role during phytoplankton and zooplankton interactions is still unresolved. Two contradictory roles were proposed for DMS and its precursor DMSP, as anti-grazing defense ${ }^{4,26}$ and pro-grazing chemoattractant ${ }^{6}$. We aimed to unravel this debate by combining functional genomics and physiological approaches to assess the impact of DMS during zooplankton-algae interactions. We used the bloom-forming cosmopolitan coccolithophore Emiliania huxleyi (Prymnesiophyceae) from which a DL enzyme was recently isolated (Alma1) ${ }^{7,27-29}$. The full characterization of Alma1 and its conservation among diverse taxa ${ }^{7}$ provided a unique opportunity to unravel its ecophysiological role. We directly manipulated DL activity in prey cells in order to determine the influence of DMS on grazing dynamics by zooplankton, focusing on microzooplankton. Microzooplankton $(20-200 \mu \mathrm{m})$ are key marine herbivores that remove $49-77 \%$ of the photosynthetic biomass daily ${ }^{30-32}$ and in fact DMS is often produced via DL activity upon disruption of algal cells during grazing ${ }^{25}$. Here, we demonstrate that DMS enhances grazing efficiency by micro- and mesozooplankton, and further discussed the ecological and evolutionary implications of DMS-mediated herbivory in the ocean.

We firstly examined the effect of DMS emission on grazing dynamics between E. huxleyi high DL strain CCMP373 and Oxyrrhis marina, a heterotrophic dinoflagellate commonly used as a model microzooplankton ${ }^{33}$. In order to directly link between algal DMS and grazing efficiency, we applied a novel selective DL-inhibitor, 2-bromo-3(dimethylsulfonio)-propionate (Br-DMSP) which blocked E. huxleyi's DL activity in-vitro ${ }^{8}$. During short-term grazing experiments in the presence of $0.2 \mu \mathrm{M}$ Br-DMSP, DMS release to the culture medium from grazed cells decreased by $\sim 50 \%$, compared to control 
culture (Fig. 1a,b and Supplementary Fig. 1). Imaging of the grazer's food vacuole by florescence microscopy revealed that inhibition of DL activity led to $>50 \%$ reduction in prey content as compared to ingestion of control cells after 0.5 and $3 \mathrm{~h}$ of predation (Fig. 1c,d). Furthermore, the ingestion rate on Br-DMSP treated cells declined by $\sim 74 \%(\sim 35 \mathrm{E}$. huxleyi grazer $^{-1}$ day $\left.^{-1}\right)$ as compared to untreated control cells $\left(\sim 133\right.$ E. huxleyi grazer ${ }^{-1}$ day $^{-}$ ${ }^{1}$ ), based on quantification of prey clearance by flow-cytometry (Fig. 1e). Notably, even partial inhibition of DL activity led to pronounced reduction in grazing rate. As a control for a possible indirect effect of Br-DMSP, we used the green alga Dunaliella tertiolecta as prey since it lacks the DL enzyme. Indeed, no change was detected in the consumption of D. tertiolecta by O. marina in the presence of Br-DMSP (Supplementary Table 1).

a
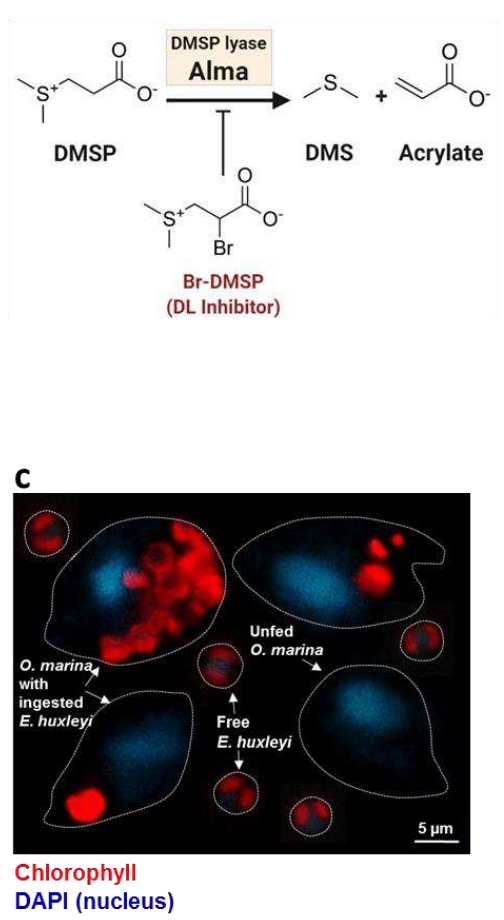

b

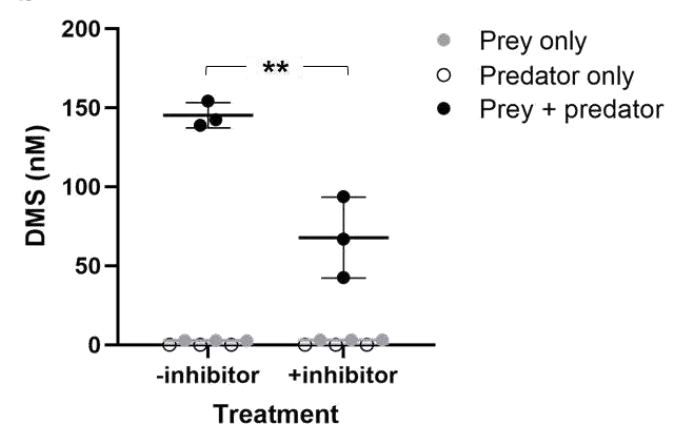

d

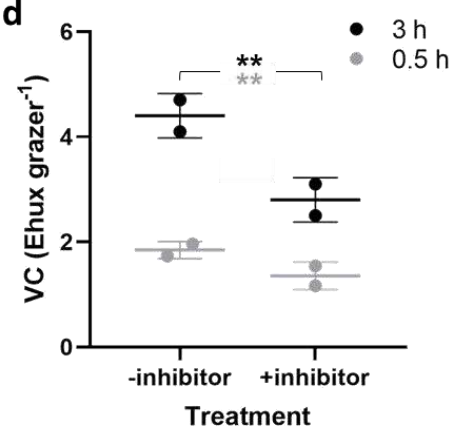

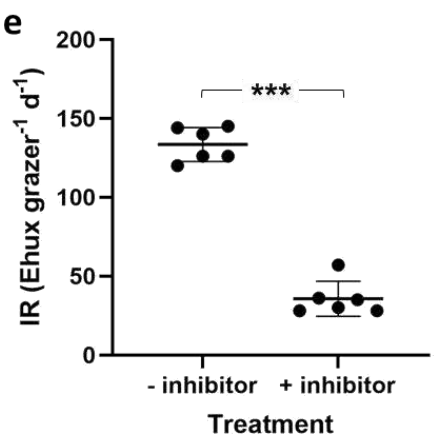

Fig 1. Reduced DMSP lyase (DL) activity of $E$. huxleyi impaired grazing by $O$. marina. a, The by forming an enzyme-inhibitor covalent bond at the active site, thus inhibiting the formation of DMS and acrylate ${ }^{8}$. b, The short-term $(\sim 1 \mathrm{~h})$ effect of $0.2 \mu \mathrm{M}$ Br-DMSP on DMS production invivo by $E$. huxleyi 373. Horizontal lines represent the mean $\pm \mathrm{SD} ; n=3 ; P<0.008$ (Student's Ttest). c, Fluorescence micrograph collage of $O$. marina with free and ingested $E$. huxleyi cells at $\mathrm{t}=30$ minutes from prey addition. $\mathbf{d}$, The effect of $0.2 \mu \mathrm{m}$ Br-DMSP on the food vacuole content (VC, E. huxleyi 373 cells per grazer) of $O$. marina at $\mathrm{t}=0.5$ and $3 \mathrm{~h}$. A total of 800 O. marina cells were examined, 100 cells per biological replicate. Horizontal lines represent the mean \pm SD; $n=2$; $P<0.003$ (generalized linear mixed model). e, The effect of $0.2 \mu \mathrm{m} \mathrm{Br-DMSP}$ on ingestion rate (IR) of E. huxleyi 373 cells (Ehux) by $O$. marina, quantified by flow cytometry and based on prey removal from the medium during $50 \mathrm{~min}$. Approximately 2,500 cells were analyzed per sample. 
E. huxleyi cells produce minimal amounts of DMS during exponential growth (Fig. 1b and Supplementary Fig. 2), probably because the DL and its substrate DMSP are segregated in different subcellular compartments ${ }^{34}$. However, algal senescence and interactions with viruses $^{11,35}$, and as we show here with grazers (Fig. 1b and Supplementary Fig. 2), trigger DL activity and significant DMS production, probably as a result of damaged cellular membranes and mixing of DL and DMSP ${ }^{36-38}$. Here, inhibition of the prey's DL activity suppressed grazing efficiency by $O$. marina. Hence, we hypothesize that increasing DL activity will enhance the grazing response by microzooplankton. Exogenous application of DMS or acrylate (the products of DL activity, Fig. 1a) to E. huxleyi strain CCMP2090, which has low DL activity and produces no detectable DMS, did not significantly alter the grazing response by $O$. marina (Supplementary Fig. 3). It is likely that bulk addition failed to mimic the natural spatiotemporal DMS gradients in seawater and in the cell's microenvironment. Thus, the cellular release of infochemicals during microbial interactions may be critical for understanding their signaling role. In order to directly address the biological context of DMS release, genetic manipulation of the DL enzyme in prey cells is critical. As E. huxleyi and other major DMS producing species are yet to be genetically amendable, we conducted heterologous expression of the E. huxleyi DL gene in the ecologically important diatom species Thalassiosira pseudonana ${ }^{39-42} . T$. pseudonana is similar in size to E. huxleyi (3-5 $\mu \mathrm{m})$ and synthesizes DMSP $\left(\sim 10 \mathrm{mM}^{\text {cell }}{ }^{-}\right.$ $\left.{ }^{1}\right)^{43}$, but lacks a DMSP lyase and does not produce DMS ${ }^{7,43}$. Thus, transgenic $T$. pseudonana can serve as a tractable model system to study the direct signaling role of DMS during grazing interactions. We overexpressed the DMSP lyase encoding gene from $E$. huxleyi 373 (almal) in T. pseudonana and fused it to GFP at the C-terminus in order to preserve a putative target sequence at the N-terminus (Fig. 2a,b and Supplementary Fig. 4). The heterologous expression of the E. huxleyi DL in a transgenic T. pseudonana line, called Tp DL-GFP, was verified by western blot using an antibody raised against the Alma1 protein (Supplementary Fig. 4b). DL enzymatic activity in Tp DL-GFP cell lysate (8.8 \pm $2.9 \mathrm{fmol}^{\mathrm{DMS}}$ cell $^{-1} \mathrm{~min}^{-1}$, Fig. 2c) was comparable to E. huxleyi high DL strains ${ }^{7,44}$. Both the morphology and growth dynamic of the transgenic cells were not affected by the expression of Alma1-GFP (Supplementary Fig. 5). Live Tp DL-GFP cells produced DMS levels comparable to those found in seawater samples $(\sim 9 \mathrm{nM}){ }^{45,46}$. We did not detect, however, a significant increase in DMS concentration during grazing by $O$. marina in Tp DL-GFP (Fig. 2d,e). The in-vivo DMS production in grazed Tp DL-GFP cells was predicted to be limited by the considerably lower intracellular levels of DMSP in $T$. pseudonana relative to E. huxleyi (Fig. 2c).

In order to investigate the direct effect of enhanced DL activity on grazing efficiency, we conducted feeding experiments with $O$. marina using Tp DL-GFP cells as prey. Grazers fed with Tp DL-GFP accumulated significantly more prey in their food vacuole over time (Fig. 2f). In accordance, the ingestion rate on Tp DL-GFP cells was $\sim 2-4$ fold higher than on wild type cells $\left(24 \pm 5\right.$ and $6 \pm 4 T$. pseudonana grazer $^{-1}$ day $^{-1}$ during the first 30 min, 
142 respectively. Fig. $2 \mathrm{~g}$ and Supplementary Fig. 6). Furthermore, ingestion by $O$. marina was 143 also elevated during grazing $T$. pseudonana expressing only DL (Tp DL), while ingestion 144 of $T$. pseudonana expressing only GFP (Tp-GFP) was similar to wild type (Supplementary 145 Fig. 7c and 6b). This eliminates the possibility that the prey's GFP fluorescence modulated 146 grazing activity, and indicates that enhanced grazing on Tp DL-GFP was solely due to the 147 induced DMS production. Intriguingly, daily feeding on Tp DL-GFP cells significantly 148 improved $O$. marina growth, as compared with a wild type diatom diet (Fig. 2h). Thus, DL 149 activity in prey cells not only expedited grazing dynamics, but also enhanced the grazer's 150 growth on a longer timescale. This may be attributed to general higher consumption of 151 algal biomass and to specific assimilation of the diatom's DMSP as an essential nutritious 152 sulfur $^{47}$.

153 In order to further examine if $O$. marina preferentially ingested DMS-producing cells, or 154 alternatively whether the diffusible DMS may elicit a general unselective grazing activity, 155 we conducted double-prey competition trials. The total ingestion rate of cells in a prey 156 mixture containing Tp DL-GFP and wild type cells (1:1) was over $\sim 2$ fold higher as 157 compared to ingestion on a mixture of wild type cells with Tp GFP (Fig. 2i). This indicated 158 that DMS formed by DL activity in grazed cells can increase the grazing likelihood of 159 neighboring cells with no DL activity. Therefore, DMS can potentially enhance grazing 160 within natural algal communities where only a fraction of the cells secretes DMS. Indeed, 161 during the double-prey competition trials there was no significant difference between the 162 uptake of each prey type (wild type or Tp DL-GFP), and no preference by $O$. marina 163 towards Tp DL-GFP cells (Fig. 2i). Thus, O. marina grazing on Tp DL-GFP was non164 selective, and may be attributed to dissolved chemical signals such as DMS, which acts as 165 an appetizing infochemical enhancing general grazing activity. 
a

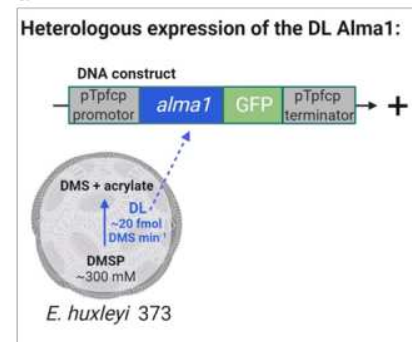

b

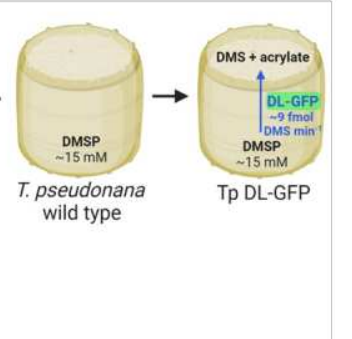

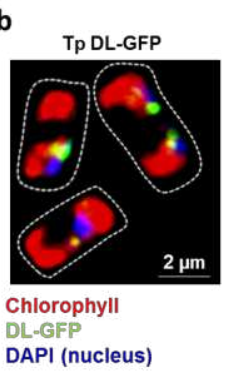
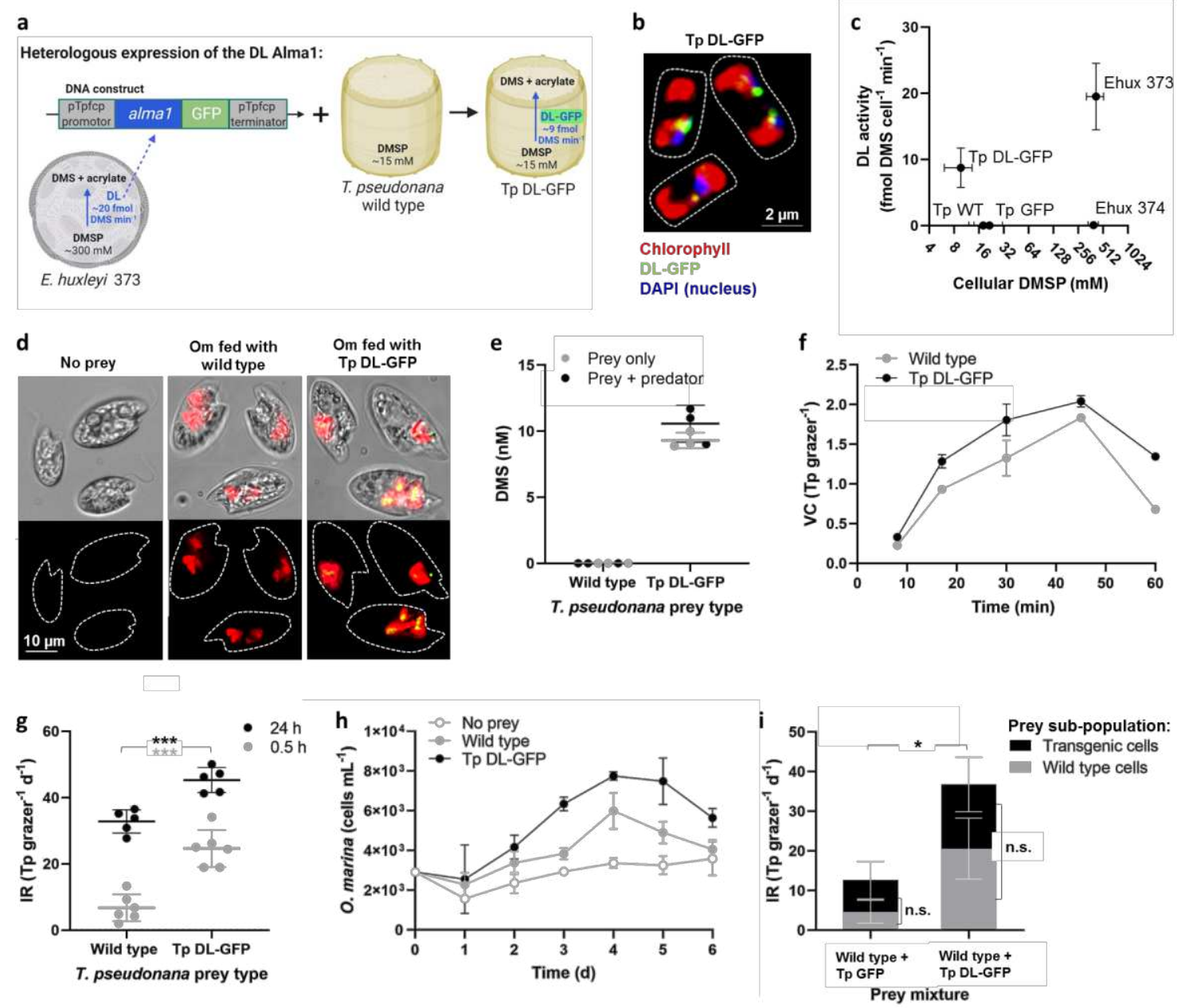

Fig. 2. Overexpression of DMSP lyase (DL) in algal prey cells enhanced grazing efficiency and growth by $\boldsymbol{O}$. marina. a, Transgenic Tp DL-GFP cells were generated by heterologous expression of the almal gene from E. huxleyi 373 , fused to GFP, in wild type T. pseudonana cells. b, Confocal microscopy of Tp DL-GFP cells. The Alma-GFP protein can be observed as a punctate green signal in close proximity to the chloroplast. c, Intracellular DMSP content and DL activity in E. huxleyi (Ehux) strains 373 and 374, as well as in T. pseudonana wild type (Tp WT), Tp GFP and Tp DL-GFP. We quantified DL activity in vitro by measuring DMS generation in cell lysates following addition of $10 \mathrm{mM}$ DMSP. Values are mean $\pm \mathrm{SD} ; n=3-4$. For DMSP, results from two independent measurements were averaged. d, Bright field and fluorescence micrographs of $O$. marina $(\mathrm{Om})$ with ingested $T$. pseudonana cells. e, DMS emission during grazing by $O$. marina on Tp DL-GFP cells. Horizontal lines represent the mean \pm SD; $n=3$. f, Prey uptake curve based on vacuole content $(\mathrm{VC})$ analysis during the first hour of grazing interaction. Values represent the mean \pm SD. $n=2-4$. A total of 800 grazers were analyzed for $\mathrm{t}=8$ and $17 \mathrm{~min}$, and 400 grazers for $\mathrm{t}=30,45$, and $60 \mathrm{~min}$. The mean VC values during $60 \mathrm{~min}$ were significantly different between the two prey types, $P<0.0001$ (generalized linear mixed model). $\mathrm{g}$, Ingestion rate (IR) analysis based on quantification of T. pseudonana (Tp) cell removal from the medium during 0.5 and $24 \mathrm{~h}$ of incubation with $O$. marina. Horizontal lines represent the mean $\pm \mathrm{SD} ; n=6 . P<0.0001$ (Student's T-test). h, Growth dynamics of $O$. marina under starvation conditions or daily feeding with Tp DLGFP or wild type cells; $n=4$. The growth in the Tp DL-GFP treatment was significantly faster than wild type, $P<0.0012$ (mixed effects model). i, Double-prey competition trials based on IR analysis 187 of two prey types introduced to $O$. marina in a 1:1 ratio, as measured over $2 \mathrm{~h}$. Values are mean \pm 
SD; $n=3-4$ in two independent experiments. $P<0.001$ when comparing the total IR between the two prey mixtures. When comparing the specific IR on each prey sub-population within a mixture, $P>0.32$, n.s.- not significant (Student's T-test).

In order to explore the prevalence of DL-mediated herbivory, grazing assays were conducted with microzooplankton from different taxa, size and feeding modes (i.e. direct engulfment or filter feeding. Fig. 3a and Supplementary Table 2). The fold-change between the grazing rate on Tp DL-GFP and Tp GFP cells, which differ only by their DL activity, was calculated for each grazer species (if the fold-change >1, DL-GFP cells were consumed faster than Tp GFP cells). As thecate dinoflagellates and ciliates are dominant consumers of E. huxleyi and are frequently observed during E. huxleyi blooms ${ }^{48}$, shortterm feeding experiments were conducted with the dinoflagellate Gyrodinium dominans and the ciliate Strombidium sp. as grazers. Like $O$. marina, Strombidium sp. consumed Tp DL-GFP prey faster than Tp GFP ( 7-fold, Fig. 3a). In contrast, G. dominans grazed similarly on both prey types. Next, we assessed grazing by larger mesozooplankton $(0.2-$ $2 \mathrm{~mm}$ ), on the transgenic diatoms. Cultured Artemia salina (brine shrimp) consumed $\mathrm{Tp}$ DL-GFP twice as fast as Tp GFP cells. Furthermore, wild calanoid copepods of the species Pleuromamma indica consumed Tp DL-GFP 28 times more than the Tp GFP control (Fig. 3a). Notably, none of the tested predators exhibited a negative grazing response toward $\mathrm{Tp}$ DL-GFP prey (fold-change $<1$ ). While DL-mediated herbivory may be species-specific, it is clearly not specific to $O$. marina alone, but shared by several important marine herbivores.

To further assess the ecological significance of DMS-mediated herbivory, we used mixed native microzooplankton assemblages from the Gulf of Aqaba in the northern Red Sea. These assemblages included a wide diversity of heterotrophic and mixotrophic species within the 5-200 $\mu \mathrm{m}$ size range, such as tintinnid ciliates, dinoflagellates, nauplii and small copepods (Supplementary Fig. 8,9). Most natural cells $<5 \mu \mathrm{m}$ were excluded during nettow harvesting. The native grazers were subsequently fed with Tp DL-GFP or Tp GFP prey cells for $24 \mathrm{~h}$. The uptake of the transgenic diatom cells by the natural grazers was confirmed by microcopy and quantified as grazing rate $\left(g\right.$, day ${ }^{-1}$ ) (Fig. 3b,c and Supplementary Fig. 10,11). Grazing rates in four independent experiments conducted during 2017-2020 were variable, perhaps due to changes in the taxonomic assortment of the grazer communities in each experimental flask. Nonetheless, in 3 out of 4 experiments, the native grazers removed the Tp DL-GFP prey cells significantly faster than the Tp GFP control. The highest average grazing rate was detected at February 2020, where Tp DLGFP cells were removed on average $\sim 10$ times faster than Tp GFP control cells $(0.22 \pm$ 0.12 day $^{-1}$, Fig. 3b). Overall, most of the cultured and wild grazers tested exhibited a varied degree of enhanced grazing on DMS-producing prey, indicating that DMS facilitates herbivory across a wide variety of zooplankton taxa representing different size and feeding strategies. To our knowledge, this is the first study to demonstrate that DL activity in algal prey cells is coupled to enhanced grazing activity by zooplankton. 

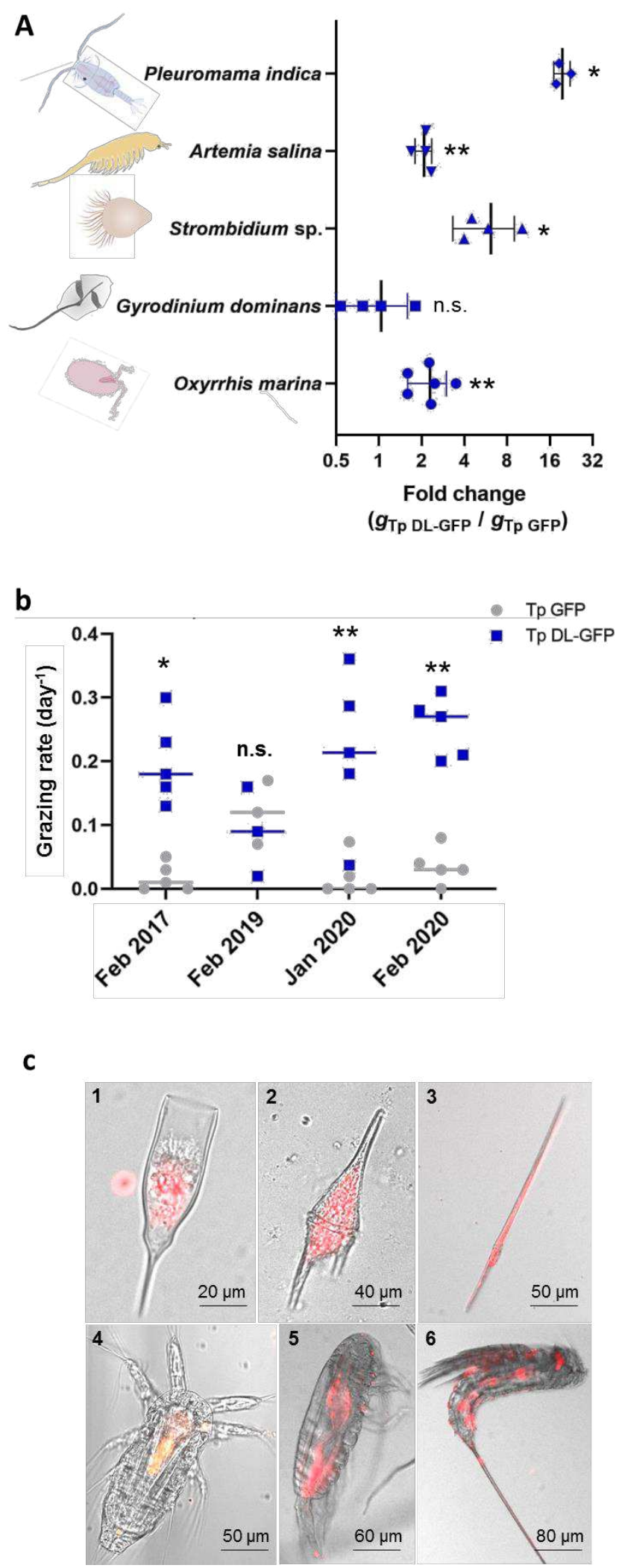

Fig. 3. Induced DMS production in algal prey enhanced grazing by diverse zooplankton. a, 231 The grazing response of diverse zooplankton fed with Tp DL-GFP cells. Tp GFP cells were used 
as control prey. The fold change in grazing rate ( $g$, as assessed by monitoring free prey cells using flow cytometry) on each prey type was calculated, where fold change $>1$ indicates faster grazing on Tp DL-GFP cells. Vertical lines represent the mean $\pm \mathrm{SD} ; n=3$ for $P$. indica; 4 for $A$. salina, G. dominans and Strombidium sp.; 6 for $O$. marina. n.s.- not significant, $P>0.897 ;{ }^{*} P<0.011$; $* * P<0.003$ (one-sample T-test). b, Grazing of Tp DL-GFP cells by natural microzooplankton from the Red Sea. Two prey types were offered to the microzooplankton assemblages: Tp GFP or Tp DL-GFP. Horizontal lines represent the mean; $n=5-6$. ${ }^{*} P<0.017$; $* * P<0.005$ (Student's Ttest). c, Variety of wild microzooplankton observed during grazing experiments shown in (b), including tintinnid ciliate (1), mixotrophic Ceratium dinoflagellates (2-3) and diverse copepods (46). Red represents the chlorophyll of ingested $T$. pseudonana cells added as prey (mixotrophic dinoflagellates also have endogenous chlorophyll).

Our new results corroborate previous studies showing that DMS and DMSP can act as chemoattractant signals for marine protists (including $O$. marina) and copepods $6,20,21,33$. We therefore propose a new ecological role for the DL enzyme, mediated by its DMS product (and/or potentially acrylate) which acts as a pro-grazing signal and accelerating the removal of algal cells by their immediate protozoan predators. The response of marine protists to the algal-derived DMS signal is analogous to the phagocytic activity of immune cells in the mammalians, which are attracted to damaged and apoptotic cells via secreted "eat-me" signals ${ }^{49}$. In light of our findings, DMS-mediated herbivory may have a significant impact on algal bloom dynamics of highly DMS-producing species like $E$. huxleyi. Since E. huxleyi strains can range in their DL activity over four order of magnitude 50-52, we hypothesize that grazing of high-DL strains can release DMS that acts as an appetizing signal, leading to enhanced grazing pressure imposed upon the entire blooming population (Fig. 4). Considering the constantly changing environmental conditions during bloom succession, and that late blooms are more prone to nutrient limitation and viral attack, DMS-mediated signaling may promote the removal of damaged, infected or aged algal populations by expediting a top-down grazing pressure. 


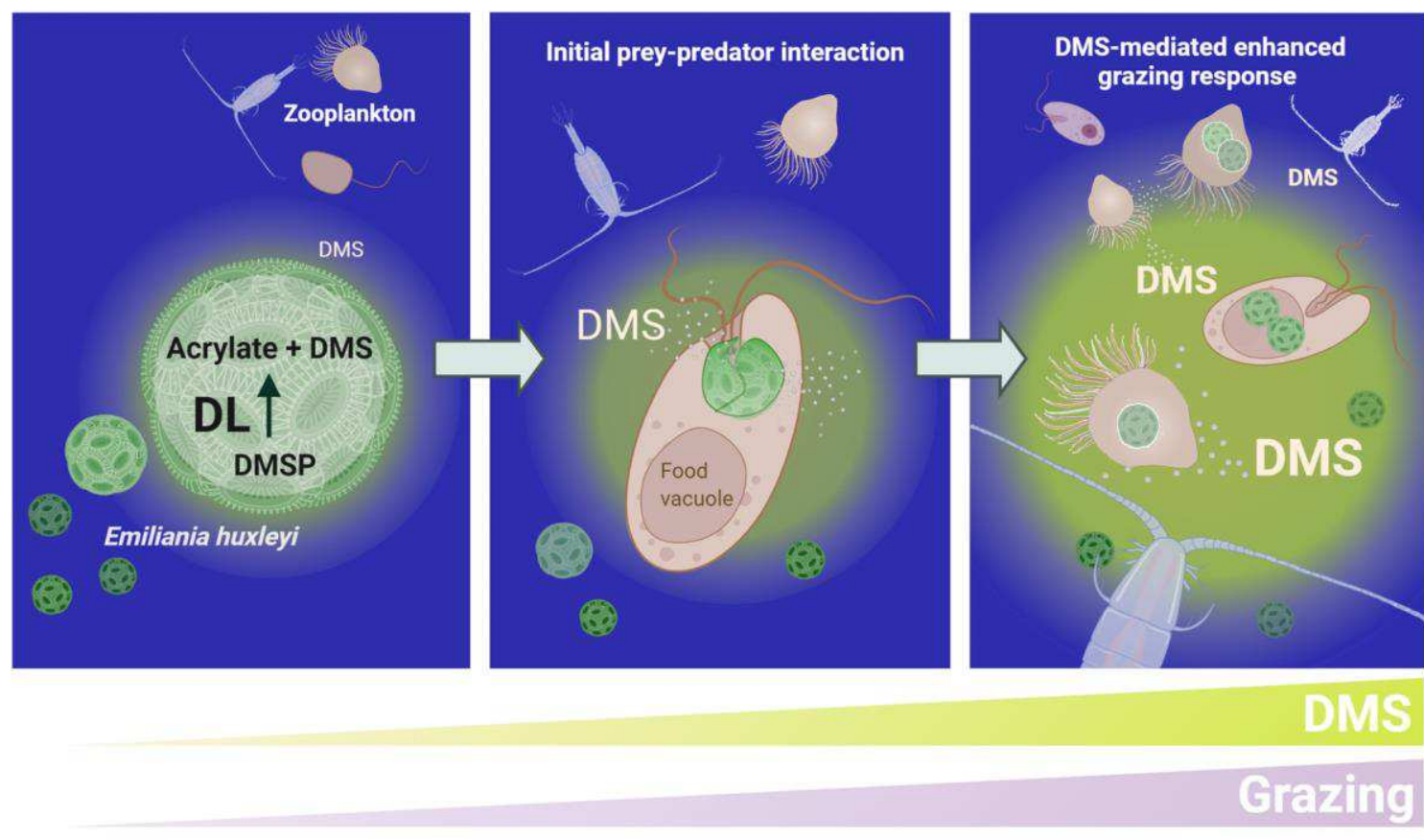

Fig. 4. The ecological impact of algal DMS on planktonic prey-predator interactions. A conceptual model describing DMS-mediated herbivory. Chemoattraction of zooplankton to leakage of DMS from high DMS producing algae such of E. huxleyi cells may facilitate initial grazing interaction (left panel). Upon dissociation of ingested cells during phagocytosis, the DL Alma1 degrades DMSP and releases more DMS into the water (middle panel). This microscale release of DMS may accumulate to high concertation, which induces an increase in the overall grazing pressure by diverse grazers on the entire phytoplankton population (right panel) and thus has wide ecological implication in the marine environment. 
Since the historical discovery of DMS from a seaweed about 85 years ago, the cellular function of this volatile, and of its generating enzyme, still remain elusive ${ }^{53}$. The unknown cellular role for the DL gene is intriguing in light of its high conservation among diverse phytoplankton species with great ecological success such as such as E. huxleyi, Phaeocystis and Symbiodinium ${ }^{7}$. While DMSP appears to serve as an osmolyte or antioxidant in several phytoplankton species ${ }^{15}$, the physiological benefit of DMSP catabolism by DL activity is still unknown. Yet, previous studies have indicated that DL activity acts as a grazingactivated chemical defense mechanism. The proposed defense role was based on grazing experiments on E. huxleyi strains displaying $\sim 4$ orders of magnitude range in the DL activity ${ }^{4,26,37,44}$. However, since the transcriptome of these E. huxleyi strains differs in expression of $\sim 10,000$ genes ${ }^{7,54}$, it is difficult to assign a specific role for a single trait as DL activity. Bulk addition of DMSP, but not of DMS or acrylate, reduced grazing rates of E. huxleyi cells by microzooplankton, suggesting a role in chemical defense ${ }^{5}$. However, it is questionable whether exogenous addition of DMS/P mimics spatiotemporal gradients in the media during prey-predator interaction. Indeed, based on our genetic and physiological approaches that enabled in-vivo modulation of DL activity, we show that DL activity enhanced grazing. Hence, the evolutionary retention of a DL gene comes with a marked cellular cost of prompting grazing by diverse herbivores. This conundrum indicates an essential role for DL activity in algal cells which is yet to be discovered.

At the ecological level, the response to DMS by zooplankton, and specifically microzooplankton as shown here, is akin to what has been previously described for higher predators such as fish, whales, birds and turtles. These top-predators utilize DMS as a foraging cue, to find 'hot-spots' of high biomass and high plankton concentrations ${ }^{22-24,55,56}$. Intriguingly, by facilitating trophic cascades, DMS may actually promote indirect defense mechanisms for the emitting phytoplankton at the population level. In the Southern Ocean, sea birds are highly sensitive to DMS emitted from Phaeocystis sp. blooms, track its source and feed mainly on krill, the main grazer of Phaeocystis sp. in this region ${ }^{22}$. In such tritrophic mutualism scenario, seabirds reduce grazing pressure on the phytoplankton. DMS was hypothesized to mediate pelagic tritrophic interactions in the plankton as well, where DMS-derived from phytoplankton-microzooplankton interaction triggers an indirect defense by attracting carnivorous mesozooplankton, which consume the microzooplankton and alleviate the grazing pressure imposed on the algal population ${ }^{57,58}$. This theory was supported by mathematical models 59,60 and evidence from coccolithophore and Phaeocystis blooms, where microzooplankton were found to be the main food source for mesozooplankton (copepods) rather than the coccolithophores directly ${ }^{61,62}$. Such copepods may be highly sensitive to DMS emitted during phytoplankton-microzooplankton grazing interaction $^{21}$. In accord, we found that mesozooplankton (copepods and krill) fed with $O$. marina cells which were pre-treated with E. huxleyi or Tp DL-GFP prey, produced higher 309 
indicate enhanced copepod predation in the presence of grazing-derived DMS (Supplementary Table 3). The interlink between algal DMS and grazing at likely different trophic levels adds a new dimension to the complex trophic interactions established in oceanic ecosystems and particularly during algal blooms.

Overall, the sensing of DMS by marine biota from diverse size ranges and taxonomic groups ${ }^{6,63}$ raises questions regarding the specificity of the DMS signal as a foraging cue, and suggests that DMS may serve as a global eat-me signal across trophic levels. The prevalence of algal-produced DMS and the ubiquity of DMS-mediated predator-prey interactions play fundamental roles in chemical communication among multiple trophic levels in the ocean.

\section{Methods}

\section{Culture maintenance}

Algal cultures (The diatom Thalassiosira pseudonana strain CCMP1335 and the coccolithophore Emiliania huxleyi CCMP373, CCMP374 and CCMP2090) were purchased from the National Center for Marine Algae and Microbiota (NCMA, East Boothbay, Maine). Dunaliella tertiolecta culture was kindly provided by Prof. Uri Pick, Weizmann Institute of Science. Oxyrrhis marina strain LB1974 was kindly provided by Dr. Matthew Johnson, Woods Hole Oceanographic Institute. Strombidium sp. and Gyrodinium dominans were isolated and kindly contributed by Dr. Albert Calbet, Institut de Ciències del Mar, CSIC. All cultures were grown at $18^{\circ} \mathrm{C}$ with $16 \mathrm{~h}: 8 \mathrm{~h}$ light:dark cycles, in light intensity of $100 \mu \mathrm{mol}$ photons $\mathrm{m}^{-2} \mathrm{~s}^{-1}$ for algal cultures and $50 \mu \mathrm{mol}$ photons $\mathrm{m}^{-2} \mathrm{~s}^{-1}$ for $O$. marina, supplied by cool white LED lights. Algae were diluted once weekly with autoclaved, $0.22 \mu \mathrm{m}$-filtered seawater (FSW) supplemented with F/2 (and silica for diatoms) ${ }^{64}$. O. marina cells were fed twice weekly with $D$. tertiolecta and were transferred every 3 weeks to a new flask containing FSW supplemented with PenStrep antibiotic solution (Sigma).

\section{Genetic transformation of $T$. pseudonana}

To overexpress the Alma1-GFP fusion protein in T. pseudonana, wild type cells were transformed using a biolistic particle delivery system fitted with 1350 psi rupture discs (BioRad). M10 tungsten particles $(0.7 \mu \mathrm{m})$ were coated with $5 \mu \mathrm{g}$ of plasmid DNA in the presence of $\mathrm{CaCl}_{2}(2.5 \mathrm{M})$ and spermidine, according to the manufacturer's instructions. The plasmid encodes for nourseothricin resistance and Alma or Alma-GFP fusion protein. Approximately $1 \times 10^{6}$ cells were spread on a plate containing solid medium (1.5\% Bacto agar in FSW + F/2) a few hours before bombardment. Bombarded cells were recovered in $\mathrm{F} / 2$ media + silica, and incubated at $18^{\circ} \mathrm{C}$ under constant light overnight. The culture was 
then plated onto solid medium containing $100 \mu \mathrm{g} \mathrm{mL} \mathrm{m}^{-1}$ nourseothricin. Plates were incubated for 10 days and resistant colonies were re-streaked onto fresh solid medium containing nourseothricin. The colonies obtained were then screened for GFP fluorescence and DL activity.

\section{Measurements of cellular DMSP, DMS emission and DMSP lyase activity}

For determination of cellular DMSP concentration, cultures $(\sim 3 \mathrm{ml})$ were acidified with $1.5 \% \mathrm{HCl}$ and stored at $4{ }^{\circ} \mathrm{C}$ for $>24$ hours ${ }^{17}$. Samples were diluted (1:100) in DDW, and DMSP was lysed to DMS by adding $\mathrm{NaOH}$ to a final concentration of $0.45 \mathrm{M}$. Glycine buffer ( $\mathrm{pH} 3$, final con. $0.8 \mathrm{M}$ ) was added in order to neutralize the solution ( $\mathrm{pH} 8$ to 9). Samples were then measured for DMS concentration in sealed glass vials, using Eclipse 4660 Purge-and-Trap Sample Concentrator system equipped with Autosampler (OI Analytical). Separation and detection were done using gas chromatography-flame photometric detector (GC-FPD, HP 5890) equipped with RT-XL sulfur column (Restek). DMS emission in-vivo was quantified in the culture media (filtered through GF/F filters, Whatman) or directly in the culture over time, in sealed glass vials $(40 \mathrm{~mL})$. The DMS measurement itself was conducted as described for the DMSP analysis. DMSP lyse activity (in-vitro) was estimated as DMS release and measured as previously described ${ }^{7}$. Cells were harvested by centrifugation. Cell pellets were resuspended in lysis buffer (Tris 100 $\mathrm{mM} \mathrm{pH} 8.0, \mathrm{NaCl} 100 \mathrm{mM}$, DTT $1 \mathrm{mM}$, Triton 100x 0.02\%, Benzonase 250 units) and sonicated. Crude lysates were incubated with $10 \mathrm{mM}$ DMSP while shaking for $10 \mathrm{~min}$ at $30^{\circ} \mathrm{C}$. Reactions were terminated by 1000 -fold dilution into sealed glass vials containing $30 \mathrm{ml}$ of distilled water. The vials were kept on ice in the dark until the DMS measurement, conducted as described for the DMSP analysis. All measurements were calibrated against a standard curve of DMS, ranging from 5 to $300 \mathrm{nM}$ (Sigma-Aldrich).

\section{Western-blot analysis}

For detection of the Alma1 protein expression, cells were harvested at exponential growth phase by centrifugation $\left(10,000 \times g, 15 \mathrm{~min}, 4^{\circ} \mathrm{C}\right)$ and plunged into liquid nitrogen. Cell pellets were then resuspended in lysis buffer and bath-sonicated ( $5.5 \mathrm{~s}$ sonication following by $10 \mathrm{~s}$ rest, $\mathrm{x} 5$ cycles). Cell lysates and recombinant Alma1, used as a positive control ${ }^{7}$, were separated on an Any kD SDS-PAGE (Bio-Rad). For western-blot analysis, we used a primary rabbit polyclonal antibody raised by immunization against the recombinant Alma1 protein ${ }^{7}$ and a secondary horseradish peroxidase-conjugated anti-rabbit antibody (SigmaAldrich). The antibodies were diluted in Tris-buffered saline containing $0.1 \%$ Tween-20 and 5\% skim-milk powder. ECL-Prime reagent (GE Healthcare) was used for detection.

\section{Scanning electron microscopy of T. pseudonana cells}

For morphological analysis of $T$. pseudonana cells, samples were collected during exponential growth phase. Samples $(1 \mathrm{~mL})$ were blotted at room temperature on Nuclepore 
track-etched polycarbonate membranes (Whatman), coated with $5 \mathrm{~nm}$ of Iridium for improved conductance, and imaged with a Sigma 500 SEM (Zeiss) using the InLens detector.

\section{Grazing assays with $O$. marina, Gyrodinium dominans and Strombidium sp.}

Grazing assays were conducted mainly with $O$. marina as predator and E. huxleyi or $T$. pseudonana as prey. Prior to the assay, microzooplankton were starved for 3 days to clear their digestive vacuole from their routine prey, D. tertiolecta. Prey cells were added to the grazer culture to reach a final prey:grazer ratio of 3:1 or 10:1 $\left(1-30 \times 10^{4}\right.$ prey cells $\left.\mathrm{mL}^{-1}\right)$. Grazer concentration was $3 \times 10^{3}$ cells $\mathrm{mL}^{-1}$. Grazing assays with $O$. marina were conducted for 0.5-24 h, as designated in each graph. For Gyrodinium dominans and Strombidium sp., grazing assay was conducted for $3 \mathrm{~h}$.

When using Br-DMSP ${ }^{8}$, the inhibitor was added to the E. huxleyi culture $2 \mathrm{~h}$ prior to grazing interaction. The inhibitor was diluted with $\mathrm{MeOH}$ and added in a final concentration of $0.2 \mu \mathrm{M}$, which was chosen based on toxicity assays (Supplementary Fig. 1). The same volume of $\mathrm{MeOH}$ was used as control. The inhibitor's toxicity for O. marina cells was tested by using SYTOX Green (Invitrogen) staining to detect compromised cell membranes. Samples were stained with a final concentration of $1 \mu \mathrm{M}$ SYTOX, incubated in the dark for $30 \mathrm{~min}$ and analyzed by an Eclipse flow cytometer, as described below (ex: $488 \mathrm{~nm}$ and em: $500-550 \mathrm{~nm}$ ). An unstained sample was used to eliminate the background signal.

\section{Determination of grazing and ingestion rates}

For grazing rate (g) and ingestion rate (IR) analyses, prey and grazer were incubated in a 24 well plate. Prey cells were also added to FSW as a growth control. Each group included 4-6 biological replicates. The plate was placed in the flow cytometer autosampler, where each well was sampled every 30 min to quantify the algal cells, for a total period of 2-4 hours. The flow cytometer, Eclipse iCyt (Sony Biotechnology Inc., Champaign, IL, USA), was equipped with $488 \mathrm{~nm}$ solid state air cooled laser, with $25 \mathrm{~mW}$ on the flow cell and with standard filter set-up. Algal cells were identified by plotting the chlorophyll fluorescence (ex: $488 \mathrm{~nm}$ and em: 663-737 nm) against side scatter. At least 2,500 cells were collected in each sample. Grazer cells were counted manually. The algal specific growth rate $(\mu)$ was calculated for the control and grazing treatments. $g$ and IR were calculated based on $\mu$ and normalized per grazer, as described by Frost ${ }^{65}$.

\section{O. marina vacuole content (VC) analysis}

Manual quantification of ingested prey was adapted from previous studies ${ }^{26}$. Incubation of prey and predator were conducted in $50 \mathrm{~mL}$ culture flasks. Sub-samples were fixed with $1 \%$ PFA at two time points $(0.5,3 \mathrm{~h})$ for E. huxleyi or during a time course for $T$. pseudonana $(8,17,30,45$ and $60 \mathrm{~min})$ prey. Fixed cells were gently transferred into an 

a microscope slide for 24 hours. Ingested prey items were counted by using an IX71S1F3-5 inverted Olympus microscope (Tokyo, Japan), equipped with an EXi Blue camera (Q Imaging, Surrey, BC, Canada). 100 grazer cells were observed per sample. The average prey content was calculated for each sample.

\section{O. marina growth curve}

To quantify the effect of DMS-producing prey on grazer growth, $O$. marina culture was divided to three dietary treatments: starvation, $T$. pseudonana wild type and Tp DL-GFP prey. Each treatment contained four $50 \mathrm{~mL}$ small flasks, which represent biological replicates. Prey cells were supplied daily and added to a final concentration of $3 \times 10^{4}$ cells

$\mathrm{mL}^{-1}$. The flasks were mounted onto a rotating plankton wheel and incubated with the growth condition indicated above. Daily samples for grazer cell count were fixed with $10 \%$ Lugol (Sigma-Aldrich) in a 24-well plate. O. marina cells were counted by using an IX71S1F-3-5 inverted Olympus microscope (described above). A total of 140-1000 cells were counted per sample.

\section{Grazing assays with natural microzooplankton assemblages}

In order to assess grazing on transgenic diatoms by natural microzooplankton, experiments were conducted during 2017-2020 at The Inter-University Institute for Marine Sciences (IUI) in Eilat, Israel. Surface water was collected from the pier area (29 $\left.50^{\prime} \mathrm{N}, 34^{\circ} 91^{\prime} \mathrm{E}\right)$ by using a concentrating plankton net $(5 \mu \mathrm{m})$. Sampled water $(4 \mathrm{~L})$ was then gently sieved through a $200 \mu \mathrm{m}$ mesh in order to obtain the 5-200 $\mu \mathrm{m}$ microzooplankton community fraction (used for the "grazing" treatment). Seawater was also filtered through $0.22 \mu \mathrm{m}$ filter to remove all cells (used for the "growth" treatment). Each water fraction $(5-200 \mu \mathrm{m}$ and $<0.22 \mu \mathrm{m}$ ) was divided to $300-830 \mathrm{~mL}$ polycarbonate flasks. Diatom cultures (Tp GFP

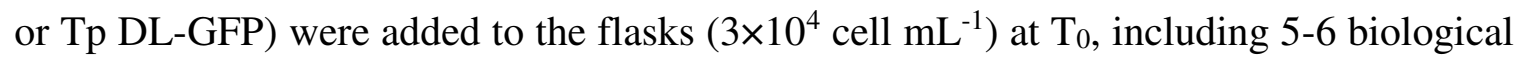
replicates. Incubation flasks were placed in a shaded water-table with ambient water temperature $\left(22-23^{\circ} \mathrm{C}\right)$ for $24 \mathrm{~h}$. In 2020 , the incubation flasks were mounted onto a rotating wheel $(0.3 \mathrm{rpm})$ and placed in the dark at $22^{\circ} \mathrm{C}$ for $24 \mathrm{~h}$. Samples for cell count were taken at $\mathrm{T}_{0}$ and after $24 \mathrm{~h}$, using FCM as describe above.

Grazing rate was calculated as previously described ${ }^{66}$. First, the growth rate was calculated for each flask as: $\mu=\left(\ln _{24}-\ln C_{0}\right) /\left(\mathrm{T}_{24}-\mathrm{T}_{0}\right)$, where $\mathrm{C}_{24}$ and $\mathrm{C}_{0}$ are the concentration of cells at $\mathrm{T}_{24}$ and $\mathrm{T}_{0}$, respectively. Then, the grazing coefficient $\mathrm{g}$ was calculated by: $\mathrm{g}=$ $\mu_{\text {growth }}-\mu_{\text {grazing, }}$ using the average $\mu$ for the growth treatment.

\section{Grazing assays with Artemia salina and Pleuromamma indica}

466 In order to assess grazing on DMS-producing prey by Artemia salina, grazing experiments were conducted with 15 days old females which were starved for 3 days. Four individuals were washed with FSW and carefully transferred using a pipette to $50 \mathrm{~mL}$ flasks containing FSW or transgenic T. pseudonana cultures (Tp DL-GFP or Tp GFP). Initial prey 
470 concentration was $1 \times 10^{5}$ cell $\mathrm{mL}^{-1}$. Algal cells were counted by FCM at $\mathrm{T}_{0}$ and $1-3 \mathrm{~h}$ and

$471 g$ was calculated as in Frost ${ }^{65}$. Grazing experiments with Pleuromamma indica were 472 conducted with wild animals collected at the northern Gulf of Aqaba, Red Sea (Station A, $47329^{\circ} 28^{\prime} \mathrm{N}, 34^{\circ} 56^{\prime}$ E) by using $300 \mu \mathrm{m}$ mesh nets. Populations $P$. indica were carefully 474 isolated from the heterogeneous assemblages. Groups of 10 individuals were transferred to 475 petri dishes with FSW for 6-10 hours to allow evacuation of their gut content. At $\mathrm{T}_{0}$, the 476 animals were transferred to incubation flasks (300 mL, 10 per flask), supplemented with 477 FSW or transgenic T. pseudonana cultures (Tp DL-GFP or Tp GFP, $3 \times 10^{4}$ cell $\mathrm{mL}^{-1}$ ). Algal 478 cells were counted by FCM at $\mathrm{T}_{0}$ and $48 \mathrm{~h}$ and $g$ was calculated as in Frost ${ }^{65}$.

\section{Mesozooplankton tritrophic grazing experiments}

481 In order to assess grazing and defecation by mesozooplankton in a tritrophic setup, samples 482 were collected during 2019-2020 at the northern Gulf of Aqaba, Red Sea (Station A, 29 $48328^{\prime} \mathrm{N}, 34^{\circ} 56^{\prime}$ E) by using $300 \mu \mathrm{m}$ mesh nets. Populations of Euphausia diomedeae, 484 Rhincalanus nasutus and Pleuromamma indica were carefully isolated from the heterogeneous assemblages. The three species were used in separate experiments, where their gut content and FP production were quantified in response to different dietary treatments. Groups of 10-12 individuals were transferred to petri dishes with FSW for 610 hours to allow evacuation of their gut content. At $\mathrm{T}_{0}$, the animals were transferred to incubation flasks $(300 \mathrm{~mL})$, supplemented with FSW or $O$. marina and phytoplankton cultures. $O$. marina was incubated with phytoplankton $\left(3 \times 10^{3}\right.$ cells $\mathrm{mL}^{-1}$ and $3 \times 10^{4}$ cells $\mathrm{mL}^{-1}$, respectively) for a few hours prior to the addition of mesozooplankton, in order for $O$. marina to feed and allow the accumulation of grazing-derived chemical cues. Incubation flasks were mounted onto a rotating wheel $(0.3 \mathrm{rpm})$ and incubated in the dark at $22^{\circ} \mathrm{C}$ for $48 \mathrm{~h}$. At $\mathrm{T}_{48}$, the animals were collected from the incubation flasks, washed with FSW and flash-frozen in liquid nitrogen (all animals from the same flask were grouped into a single tube prior to freezing). The specific ingestion of $O$. marina cells was confirmed by detecting an $O$. marina DNA sequence within the copepod gut. DNA was extracted from whole copepods by classical phenol-chloroform extraction, and then cleaned by AMPure XP beads (Beckman Coulter). Primers for quantitative PCR were designed by Primer3 and Amplify4 (William Engels, University of Wisconsin 2015) to amplify the mitochondrial 501 cob-cox3 gene, which is unique to $O$. marina 67,68. Forward primer: 5', 502 TCATGCTTTTATCTTTCTATCCA 3'; reverse 503 5'AGCTAAGAAtAAAGTAGAAGGAGA 3'. For qPCR, Platinum SYBR Green qPCR 504 SuperMix-UDG with ROX was used as described by the manufacturer (Invitrogen). 505 Reactions were performed on Step-One Plus real-time PCR System (Applied Biosystems) 506 as follows: $50{ }^{\circ} \mathrm{C}$ for $2 \mathrm{~min}, 95^{\circ} \mathrm{C}$ for $2 \mathrm{~min}, 40$ cycles of $95^{\circ} \mathrm{C}$ for $15 \mathrm{~s}, 60{ }^{\circ} \mathrm{C}$ for $30 \mathrm{~s}$. 


\section{Acknowledgments}

We thank Inbal Nussbaum and Alon Spierer for assisting in laboratory experiments; Yaara Finkel for helping in genetic transformation of $T$. pseudonana; Diana Meltzer for synthesizing Br-DMSP used in grazing experiments; Emanuel M. Avrahami for conducting scanning electron microscopy analysis for $T$. pseudonana cells; Yoav Avrahami for helping with field sampling and flow cytometry; Flora Vincent and Constanze Kuhlisch for their constructive feedback on the manuscript. We gratefully acknowledge financial support from the Israeli Science Foundation (ISF) (grant \#712233) awarded to A.V. All data are available in the supplementary materials.

Author contributions: A.S. and A.V. conceptualized the research questions and hypothesis, designed the experiments and wrote the manuscript. A.S. performed all the experiments and analyzed the data. U.A., M.J.F. and D.S.T helped in establishing the experimental system, developing the experimental tools and contributed in scientific discussions. D.S. conducted genetic transformation of T. pseudonana. A.S. and V.F. designed and conducted mesozooplankton grazing experiments. S.B.-D. performed bioinformatics analysis. R.R. performed statistical analysis.

\section{References}

1 Simó, R. Production of atmospheric sulfur by oceanic plankton: biogeochemical, ecological and evolutionary links. Trends. Ecol. Evol. 16, 287-294, doi:10.1016/S01695347(01)02152-8 (2001).

2 Charlson, R. J., Lovelock, J. E., Andreae, M. O. \& Warren, S. G. Oceanic phytoplankton, atmospheric sulphur, cloud albedo and climate. Nature 326, 655-661 (1987).

3 Wang, S., Maltrud, M. E., Burrows, S. M., Elliott, S. M. \& Cameron-Smith, P. Impacts of shifts in phytoplankton community on clouds and climate via the sulfur cycle. Global Biogeochem. Cy. 32, 1005-1026, doi:https://doi.org/10.1029/2017GB005862 (2018). 


\begin{tabular}{|c|c|c|}
\hline $\begin{array}{l}546 \\
547\end{array}$ & 4 & $\begin{array}{l}\text { Wolfe, G. V., Steinke, M. \& Kirst, G. O. Grazing-activated chemical defence in a } \\
\text { unicellular marine alga. Nature 387, 894-897 (1997). }\end{array}$ \\
\hline 548 & \multirow[t]{3}{*}{5} & Strom, S., Wolfe, G., Slajer, A., Lambert, S. \& Clough, J. Chemical defense in the \\
\hline 19 & & croplankton II: Inhibition of protist feeding by $\beta$-dimethylsulfoniopropionate (DMSP). \\
\hline 550 & & Limnol. Oceanogr. 48, 230-237, doi:10.4319/lo.2003.48.1.0230 (2003). \\
\hline 551 & \multirow[t]{3}{*}{6} & Seymour, J., Simó, R., Ahmed, T. \& Stocker, R. Chemoattraction to \\
\hline 552 & & dimethylsulfoniopropionate throughout the marine microbial food web. Science (New \\
\hline 53 & & York, N.Y.) 329, 342-345 (2010). \\
\hline 554 & \multirow[t]{3}{*}{7} & Alcolombri, U. et al. Identification of the algal dimethyl sulfide-releasing enzyme: A \\
\hline 55 & & missing link in the marine sulfur cycle. Science (New York, N.Y.) 348, 1466-1469, \\
\hline 6 & & i:10.1126/science.aab1586 (2015) \\
\hline 557 & \multirow[t]{3}{*}{8} & Alcolombri, U., Lei, L., Meltzer, D., Vardi, A. \& Tawfik, D. S. Assigning the algal source \\
\hline 558 & & of dimethylsulfide using a selective lyase inhibitor. ACS Chem. Biol. 12, 41-46, \\
\hline 559 & & doi:10.1021/acschembio.6b00844 (2017). \\
\hline 560 & \multirow[t]{3}{*}{9} & ettle, A. J. \& Andreae, M. Flux of dimethylsulfide from the oceans: A comparison of \\
\hline 561 & & lux models. J. Geophys. Res. 105, \\
\hline 62 & & $000)$ \\
\hline 563 & \multirow[t]{2}{*}{10} & Carpenter, L. J., Archer, S. D. \& Beale, R. Ocean-atmosphere trace gas exchange. Chem. \\
\hline 564 & & Soc. Rev. 41, 6473-6506, doi:10.1039/C2CS35121H (2012). \\
\hline 565 & \multirow[t]{4}{*}{11} & Franklin, D. J. et al. Identification of senescence and death in Emiliania huxleyi and \\
\hline 66 & & Thalassiosira pseudonana: Cell staining, chlorophyll alterations, and \\
\hline 57 & & dimethylsulfoniopropionate (DMSP) metabolism. Limnol. Oceanogr. 57, 305-317, \\
\hline 568 & & doi:10.4319/lo.2012.57.1.0305 (2012). \\
\hline 569 & \multirow[t]{3}{*}{12} & Keller, M. D. Dimethyl sulfide production and marine phytoplankton: the importance of \\
\hline 570 & & species composition and cell size. Biol. Oceanogr. 6, 375-382, \\
\hline 571 & & doi:10.1080/01965581.1988.10749540 (1989). \\
\hline 572 & \multirow[t]{3}{*}{13} & Curson, A. R. J. et al. DSYB catalyses the key step of dimethylsulfoniopropionate \\
\hline & & thesis in many phytoplankton. Nat. Microbiol. 3, 4 \\
\hline 574 & & 0119-5 (2018). \\
\hline 575 & \multirow[t]{4}{*}{14} & Sunda, W., Kieber, D. J., Kiene, R. P. \& Huntsman, S. An antioxidant function for DMSP \\
\hline 576 & & $\begin{array}{llllll}\text { and } & \text { DMS } & \text { marine } & \text { algae. } & \text { Nature } & \text { 417-320, }\end{array}$ \\
\hline 577 & & doi:http://www.nature.com/nature/journal/v418/n6895/suppinfo/nature00851_S1.html \\
\hline 57 & & \\
\hline 79 & \multirow[t]{3}{*}{15} & Kirst, G. O. in Biological and environmental chemistry of DMSP and related sulfoniur \\
\hline & & ter T Vischer Maureen D Keller \& \\
\hline 581 & & irst) $121-129$ (Springer US, 1996). \\
\hline 582 & \multirow[t]{3}{*}{16} & Darroch, L. et al. Effect of short-term light and UV stress on DMSP, DMS, and DMSP \\
\hline 583 & & lyase activity in Emiliania huxleyi. Aquat. Microb. Ecol. 74, 173-185, \\
\hline 584 & & doi:10.3354/ame01735 (2015). \\
\hline 585 & \multirow[t]{3}{*}{17} & Barak-Gavish, N. et al. Bacterial virulence against an oceanic \\
\hline & & phytoplankter is mediated by algal DMSP. Sci. $A d v . \mathbf{4}$, eaau5716, \\
\hline 587 & & doi:10.1126/sciadv.aau5716 (2018). \\
\hline 588 & 18 & Amin, S. A. et al. Interaction and signalling between a cosmopolitan phytoplankton and \\
\hline 589 & & 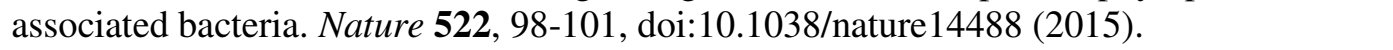 \\
\hline 590 & 19 & Garcés, E., Alacid, E., Reñé, A., Petrou, K. \& Simó, R. Host-released dimethylsulphide \\
\hline & & activates the dinoflagellate parasitoid Parvilucifera sinerae. ISME J. 7, 1065-1068, \\
\hline & & \\
\hline 593 & 20 & Steinke, M., Stefels, J. \& Stamhuis, E. Dimethyl sulfide triggers search behavior \\
\hline & & pepods. Limnol. Oceanogr. 51, 1925-1930, doi:10.4319/lo.2006.51.4.1925 (2006). \\
\hline
\end{tabular}


21 Breckels, M., Bode, N., Codling, E. \& Steinke, M. Effect of grazing-mediated dimethyl sulfide (DMS) production on the swimming behavior of the copepod Calanus helgolandicus. Mar. Drugs 11, 2486 (2013).

22 Savoca, M. S. \& Nevitt, G. A. Evidence that dimethyl sulfide facilitates a tritrophic mutualism between marine primary producers and top predators. Proc. Natl. Acad. Sci. U.S.A. 111, 4157-4161, doi:10.1073/pnas.1317120111 (2014).

23 Bouchard, B. et al. Behavioural responses of humpback whales to food-related chemical stimuli. PLOS ONE 14, e212515, doi:10.1371/journal.pone.0212515 (2019).

24 Endres, C. S. \& Lohmann, K. J. Perception of dimethyl sulfide (DMS) by loggerhead sea turtles: a possible mechanism for locating high-productivity oceanic regions for foraging. J. Exp. Biol. 215, 3535-3538, doi:10.1242/jeb.073221 (2012).

25 Simó, R. et al. The quantitative role of microzooplankton grazing in dimethylsulfide (DMS) production in the NW Mediterranean. Biogeochemistry, doi:10.1007/s10533-0180506-2 (2018).

26 Strom, S. et al. Chemical defense in the microplankton I: Feeding and growth rates of heterotrophic protists on the DMS-producing phytoplankter Emiliania huxleyi. Limnol Oceanogr. 48, 217-229, doi:10.4319/lo.2003.48.1.0217 (2003).

27 Lehahn, Y. et al. Decoupling physical from biological processes to assess the impact of viruses on a mesoscale algal bloom. Curr. Biol. 24, 2041-2046, doi:10.1016/j.cub.2014.07.046 (2014).

28 Laber, C. P. et al. Coccolithovirus facilitation of carbon export in the North Atlantic. Nat. Microbiol. 3, 537-547, doi:10.1038/s41564-018-0128-4 (2018).

29 Burkill, P. et al. Dimethyl sulphide biogeochemistry within a coccolithophore bloom (DISCO): An overview. DEEP-SEA RES PT II 49, 2863-2885, doi:10.1016/S09670645(02)00061-9 (2002).

30 Calbet, A. \& Landry, M. R. Phytoplankton growth, microzooplankton grazing, and carbon cycling in marine systems. Limnol. Oceanogr. 49, 51-57, doi:10.4319/lo.2004.49.1.0051 (2004).

31 Schmoker, C., Hernández-León, S. \& Calbet, A. Microzooplankton grazing in the oceans: impacts, data variability, knowledge gaps and future directions. J. Plankton. Res. 35, 691706, doi:10.1093/plankt/fbt023 (2013).

32 Landry, M. R. \& Calbet, A. Microzooplankton production in the oceans. ICES J. Mar. Sci. 61, 501-507, doi:10.1016/j.icesjms.2004.03.011 (2004).

33 Breckels, M. N., Roberts, E. C., Archer, S. D., Malin, G. \& Steinke, M. The role of dissolved infochemicals in mediating predator-prey interactions in the heterotrophic dinoflagellate Oxyrrhis marina. J. Plankton. Res. 33, 629-639, doi:10.1093/plankt/fbq114 (2010).

34 Raina, J. B. et al. Subcellular tracking reveals the location of dimethylsulfoniopropionate in microalgae and visualises its uptake by marine bacteria. eLife 6, e23008, doi:10.7554/eLife.23008 (2017).

35 Evans, C., Kadner, S. V. \& Darroch, L. J. The relative significance of viral lysis and microzooplankton grazing as pathways of dimethylsulfoniopropionate (DMSP) cleavage: An Emiliania huxleyi culture study. Limnol. Oceanogr. 52, 1036-1045 (2007).

36 van Rijssel, M. \& Gieskes, W. W. C. Temperature, light, and the dimethylsulfoniopropionate (DMSP) content of Emiliania huxleyi (Prymnesiophyceae). $J$. Sea Res. 48, 17-27, doi:https://doi.org/10.1016/S1385-1101(02)00134-X (2002).

37 Wolfe, G. V. \& Steinke, M. Grazing-activated production of dimethyl sulfide (DMS) by two clones of Emiliania huxleyi. Limnol. Oceanogr. 41, 1151-1160, doi:10.4319/lo.1996.41.6.1151 (1996). 
38 Daly, K. L. \& DiTullio, G. R. in Biological and environmental chemistry of DMSP and related sulfonium compounds (eds Ronald P. Kiene, Pieter T. Visscher, Maureen D. Keller, \& Gunter O. Kirst) 223-238 (Springer US, 1996).

39 Poulsen, N., Chesley, P. M. \& Kröger, N. Molecular genetic manipulation of the diatom Thalassiosira pseudonana (bacillariophyceae). J. Phycol. 42, 1059-1065, doi:10.1111/j.1529-8817.2006.00269.x (2006).

40 Saade, A. \& Bowler, C. Molecular tools for discovering the secrets of diatoms. BioScience 59, 757-765, doi:10.1525/bio.2009.59.9.7 (2009).

41 Armbrust, E. V. et al. The genome of the diatom Thalassiosira pseudonana: ecology, evolution, and metabolism. Science (New York, N.Y.) 306, 79-86, doi:10.1126/science.1101156 (2004).

42 Malviya, S. et al. Insights into global diatom distribution and diversity in the world's ocean. Proc. Natl. Acad. Sci. U.S.A. 113, E1516-1525, doi:10.1073/pnas.1509523113 (2016).

43 Kettles, N. L., Kopriva, S. \& Malin, G. Insights into the regulation of DMSP synthesis in the diatom Thalassiosira pseudonana through APR activity, proteomics and gene expression analyses on cells acclimating to changes in salinity, light and nitrogen. PLOS ONE 9, e94795, doi:10.1371/journal.pone.0094795 (2014).

44 Steinke, M., Wolfe, G. V. \& Kirst, G. O. Partial characterisation of dimethylsulfoniopropionate (DMSP) lyase isozymes in 6 strains of Emiliania huxleyi. Mar. Ecol. 175, 215-225 (1998).

45 Lana, A. et al. An updated climatology of surface dimethlysulfide concentrations and emission fluxes in the global ocean. Global Biogeochem. Cyc. 25, doi:10.1029/2010gb003850 (2011).

46 Royer, S. J. et al. A high-resolution time-depth view of dimethylsulphide cycling in the surface sea. Sci. Rep. 6, 32325, doi:10.1038/srep32325 (2016).

47 Saló, V., Simó, R., Vila-Costa, M. \& Calbet, A. Sulfur assimilation by Oxyrrhis marina feeding on a 35S-DMSP-labelled prey. Environ. Microbiol. 11, 3063-3072, doi:10.1111/j.1462-2920.2009.02011.x (2009).

48 Olson, M. B. \& Strom, S. L. Phytoplankton growth, microzooplankton herbivory and community structure in the southeast Bering Sea: insight into the formation and temporal persistence of an Emiliania huxleyi bloom. DEEP-SEA RES PT II 49, 5969-5990, doi:https://doi.org/10.1016/S0967-0645(02)00329-6 (2002).

49 Li, W. Eat-me signals: keys to molecular phagocyte biology and "appetite" control. J. Cell Physiol. 227, 1291-1297, doi:10.1002/jcp.22815 (2012).

50 Read, B. A. et al. Pan genome of the phytoplankton Emiliania underpins its global distribution. Nature 499, 209-213, doi:10.1038/nature12221 (2013).

51 Martínez, J. M., Schroeder, D. C. \& Wilson, W. H. Dynamics and genotypic composition of Emiliania huxleyi and their co-occurring viruses during a coccolithophore bloom in the North Sea. FEMS Microbiol. Ecol. 81, 315-323, doi:10.1111/j.1574-6941.2012.01349.x (2012).

52 Krueger-Hadfield, S. A. et al. Genotyping an Emiliania huxleyi (prymnesiophyceae) bloom event in the North Sea reveals evidence of asexual reproduction. Biogeosciences 11, 52155234, doi:10.5194/bg-11-5215-2014 (2014).

53 Haas, P. The liberation of methyl sulphide by seaweed. Biochem. J. 29, 1297-1299, doi:10.1042/bj0291297 (1935).

54 von Dassow, P. et al. Transcriptome analysis of functional differentiation between haploid and diploid cells of Emiliania huxleyi, a globally significant photosynthetic calcifying cell. Genome Biol. 10, R114, doi:10.1186/gb-2009-10-10-r114 (2009).

55 Foretich, M. A., Paris, C. B., Grosell, M., Stieglitz, J. D. \& Benetti, D. D. Dimethyl sulfide is a chemical attractant for reef fish larvae. Sci. Rep. 7, 2498, doi:10.1038/s41598-01702675-3 (2017). 
56 Savoca, M. S. Chemoattraction to dimethyl sulfide links the sulfur, iron, and carbon cycles in high-latitude oceans. Biogeochemistry 138, 1-21, doi:10.1007/s10533-018-0433-2 (2018).

57 Steinke, M., Malin, G. \& Liss, P. Trophic interactions in the sea: An ecological role for climate relevant volatiles? J. Phycol. 38, 630-638, doi:10.1046/j.1529-8817.2002.02057.x (2002).

58 Pohnert, G., Steinke, M. \& Tollrian, R. Chemical cues, defence metabolites and the shaping of pelagic interspecific interactions. Trends Ecol. Evol. 22, 198-204, doi:10.1016/j.tree.2007.01.005 (2007).

59 Lewis, N. et al. Grazing-induced production of DMS can stabilize food-web dynamics and promote the formation of phytoplankton blooms in a multitrophic plankton model. Biogeochemistry 110, 303-313, doi:10.1007/s10533-011-9649-0 (2012).

60 Lewis, N. D. Role of infochemical mediated zooplankton grazing in a phytoplankton competition model. Ecol. complex. 16, pp. 41-50-2013 v.2016, doi:10.1016/j.ecocom.2012.10.003 (2013).

61 Hansen, F. C., Reckermann, M., Breteler, W. C. M. K. \& Riegman, R. Phaeocystis blooming enhanced by copepod predation on protozoa: evidence from incubation experiments. Mar. Ecol. Prog. Ser. 102, $51-57$ (1993).

62 Levasseur, M. et al. Production of DMSP and DMS during a mesocosm study of an Emiliania huxleyi bloom: Influence of bacteria and Calanus finmarchicus grazing. Mar. Biol. 126, 609-618, doi:10.1007/BF00351328 (1996).

63 Buchan, A., LeCleir, G. R., Gulvik, C. A. \& González, J. M. Master recyclers: features and functions of bacteria associated with phytoplankton blooms. Nat. Rev. Microbiol. 12, 686, doi:10.1038/nrmicro3326 (2014).

64 Guillard, R. R. L. \& Ryther, J. H. Studies of marine planktonic diatoms. I. Cyclotella nana Hustedt, and Detonula confervacea (cleve) Gran. Can. J. Microbiol. 8, 229-239, doi:10.1139/m62-029 (1962).

65 Frost, B. W. Effects of size and consentration of food particles on the feeding behavior of the marine planktonic copeopd Calanur Pacificus. Limnol. Oceanogr. 17, 805-815, doi:10.4319/lo.1972.17.6.0805 (1972).

66 Johnson, M. D., Michelle, R. \& Stoecker, D. K. Microzooplankton grazing on Prorocentrum minimum and Karlodinium micrum in Chesapeake Bay. Limnol. Oceanogr. 48, 238-248, doi:10.4319/lo.2003.48.1.0238 (2003).

67 Slamovits, C. H., Saldarriaga, J. F., Larocque, A. \& Keeling, P. J. The highly reduced and fragmented mitochondrial genome of the early-branching dinoflagellate Oxyrrhis marina shares characteristics with both apicomplexan and dinoflagellate mitochondrial genomes. J. Mol. Biol. 372, doi:10.1016/j.jmb.2007.06.085 (2007).

68 Untergasser, A. et al. Primer3Plus, an enhanced web interface to Primer3. Nucleic acids Res. 35, W71-74, doi:10.1093/nar/gkm306 (2007). 


\section{Figures}

a

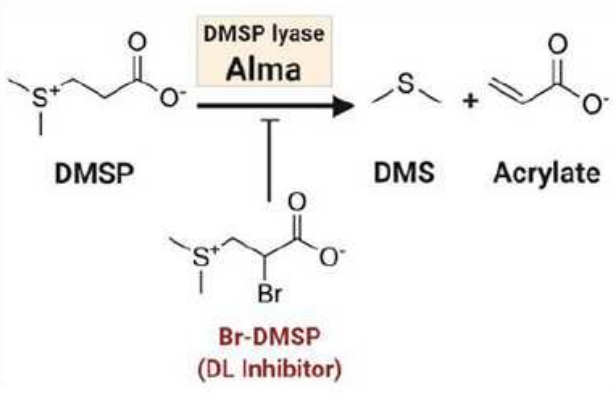

C

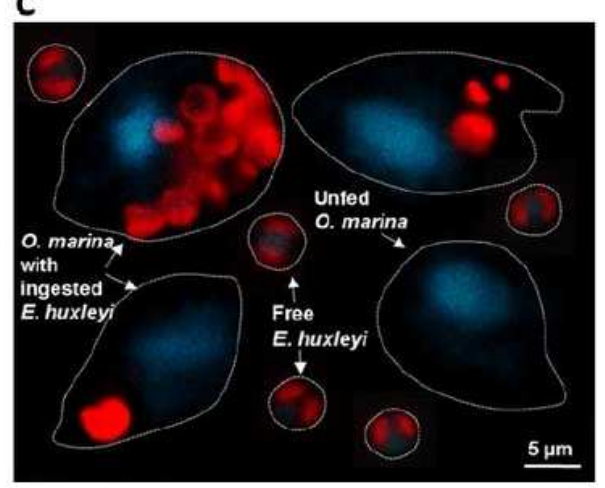

Chlorophyll

DAPI (nucleus) b

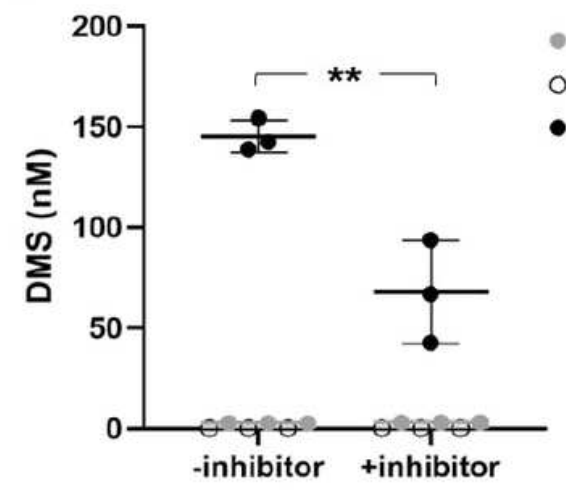

Treatment

d

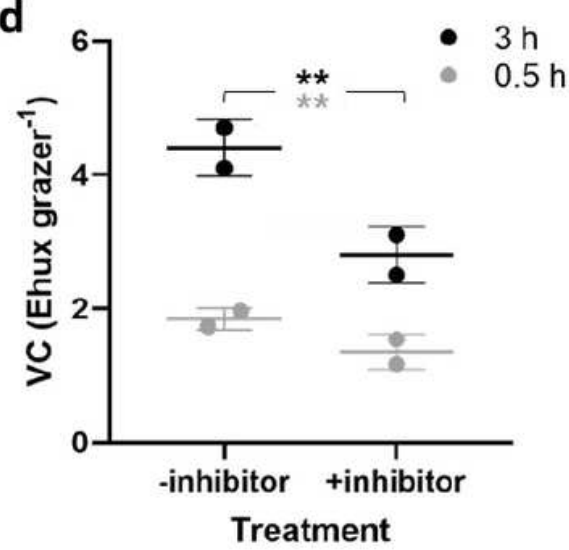

Prey only

- Predator only

- Prey + predator

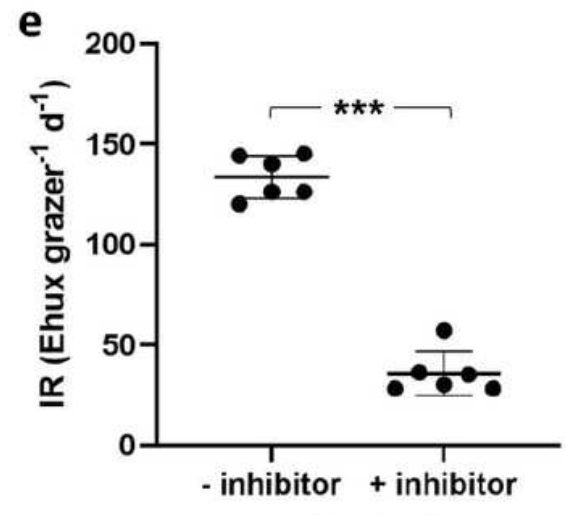

Treatment

Figure 1

Reduced DMSP lyase (DL) activity of E. huxleyi impaired grazing by O. marina. a, The DMSP lyase Alma cleaves DMSP to DMS and acrylate. The inhibitor Br-DMSP blocks DL activity by forming an enzymeinhibitor covalent bond at the active site, thus inhibiting the formation of DMS and acrylate $8 . b$, The short-term $(\sim 1 \mathrm{~h})$ effect of $0.2 \mu \mathrm{M}$ Br-DMSP on DMS production in-vivo by E. huxleyi 373 . Horizontal lines represent the mean $\pm S D ; n=3 ; P<0.008$ (Student's T-test). c, Fluorescence micrograph collage of 0 . marina with free and ingested $E$. huxleyi cells at $t=30$ minutes from prey addition. $d$, The effect of $0.2 \mu \mathrm{m}$ Br-DMSP on the food vacuole content (VC, E. huxleyi 373 cells per grazer) of 0 . marina at $t=0.5$ and $3 \mathrm{~h}$. A total of 800 O. marina cells were examined, 100 cells per biological replicate. Horizontal lines represent the mean $\pm S D ; n=2 ; P<0.003$ (generalized linear mixed model). e, The effect of $0.2 \mu \mathrm{m} \mathrm{Br-DMSP}$ on ingestion rate (IR) of E. huxleyi 373 cells (Ehux) by 0 . marina, quantified by flow cytometry and based on prey removal from the medium during $50 \mathrm{~min}$. Approximately 2,500 cells were analyzed per sample. Horizontal lines represent the mean $\pm S D ; n=6 ; P<0.0001$ (Student's T-test). 
a

Heterologous expression of the DL Alma1:
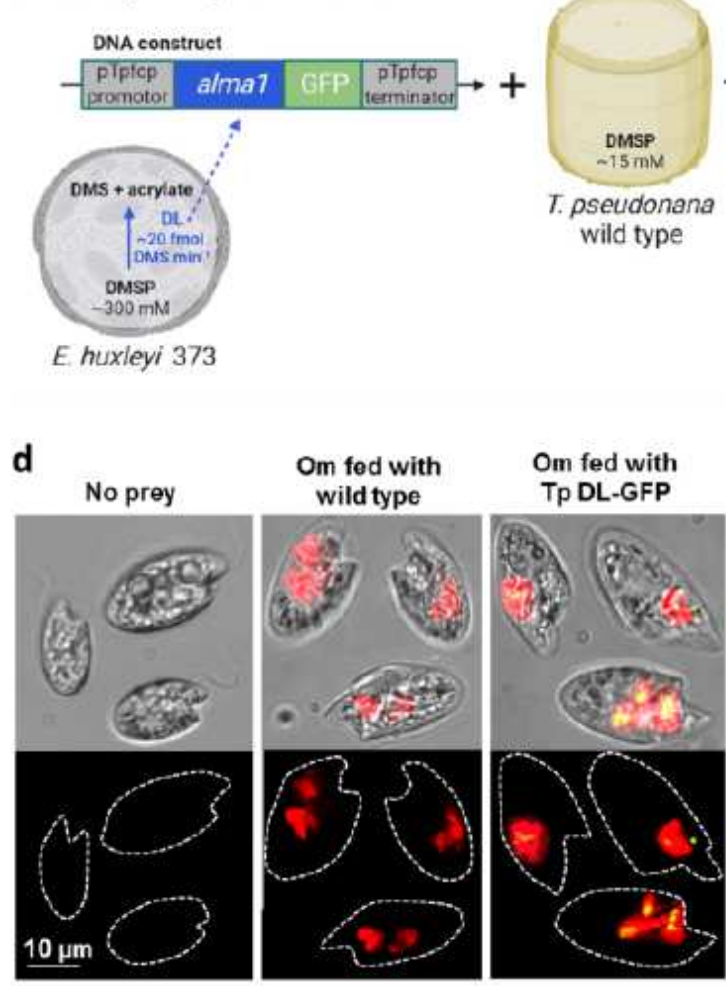

e

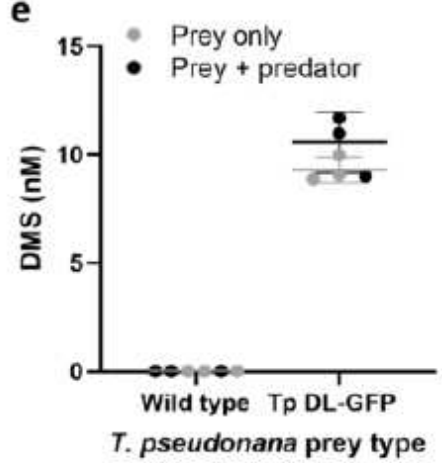

f

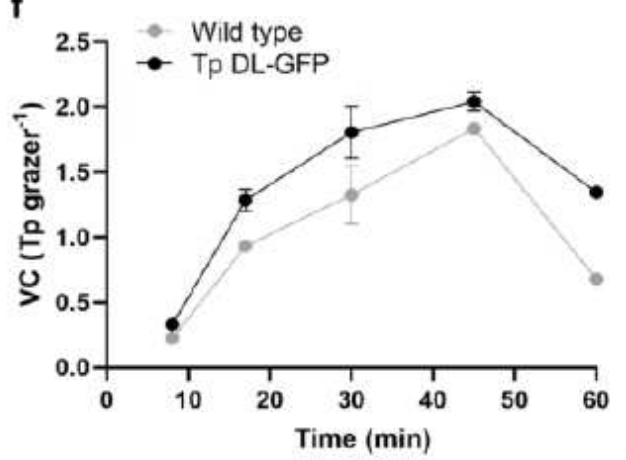

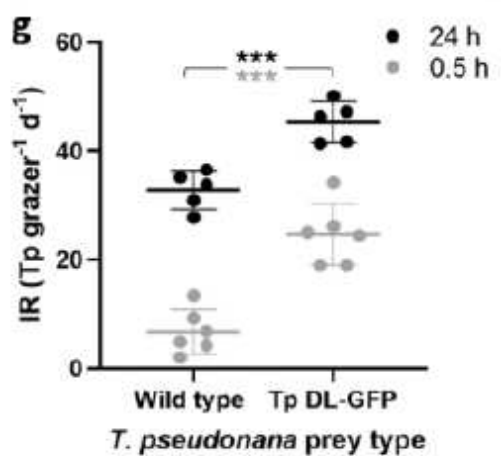

T. pseudonana prey type
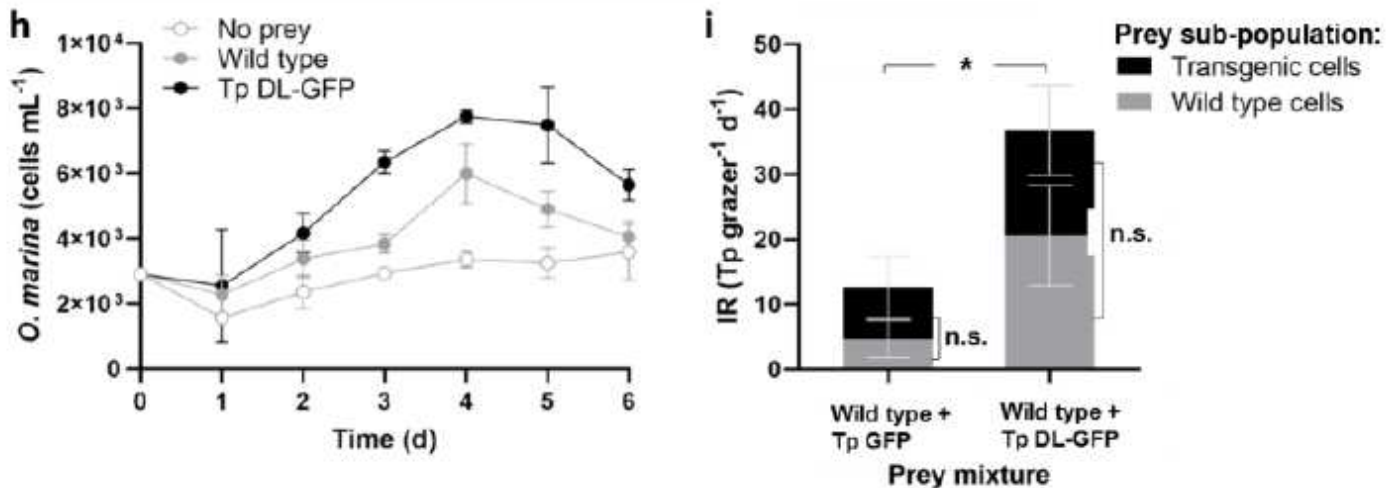

Figure 2

Overexpression of DMSP lyase (DL) in algal prey cells enhanced grazing efficiency and growth by 0 . marina. a, Transgenic Tp DL-GFP cells were generated by heterologous expression of the alma1 gene from E. huxleyi 373, fused to GFP, in wild type T. pseudonana cells. b, Confocal microscopy of Tp DL-GFP cells. The Alma-GFP protein can be observed as a punctate green signal in close proximity to the chloroplast. c, Intracellular DMSP content and DL activity in E. huxleyi (Ehux) strains 373 and 374, as well as in T. pseudonana wild type (Tp WT), Tp GFP and Tp DL-GFP. We quantified DL activity in vitro by measuring DMS generation in cell lysates following addition of $10 \mathrm{mM}$ DMSP. Values are mean \pm SD; $n=$ 3-4. For DMSP, results from two independent measurements were averaged. d, Bright field and fluorescence micrographs of $\mathrm{O}$. marina $(\mathrm{Om})$ with ingested T. pseudonana cells. e, DMS emission during grazing by 0 . marina on Tp DL-GFP cells. Horizontal lines represent the mean $\pm S D ; n=3$. $f$, Prey uptake curve based on vacuole content (VC) analysis during the first hour of grazing interaction. Values 
represent the mean $\pm S D$. $n=2-4$. A total of 800 grazers were analyzed for $t=8$ and 17 min, and 400 grazers for $t=30,45$, and $60 \mathrm{~min}$. The mean VC values during $60 \mathrm{~min}$ were significantly different between the two prey types, $\mathrm{P}<0.0001$ (generalized linear mixed model). g, Ingestion rate (IR) analysis based on quantification of T. pseudonana (Tp) cell removal from the medium during 0.5 and $24 \mathrm{~h}$ of incubation with 0 . marina. Horizontal lines represent the mean $\pm S D ; n=6$. $P<0.0001$ (Student's T-test). h, Growth dynamics of O. marina under starvation conditions or daily feeding with Tp DL-GFP or wild type cells; $n=$ 4. The growth in the Tp DL-GFP treatment was significantly faster than wild type, $P<0.0012$ (mixed effects model). i, Double-prey competition trials based on IR analysis of two prey types introduced to 0 . marina in a 1:1 ratio, as measured over $2 \mathrm{~h}$. Values are mean $\pm S D ; n=3-4$ in two independent experiments. $P<0.001$ when comparing the total IR between the two prey mixtures. When comparing the specific IR on each prey sub-population within a mixture, $P>0.32$, n.s.- not significant (Student's T-test). 

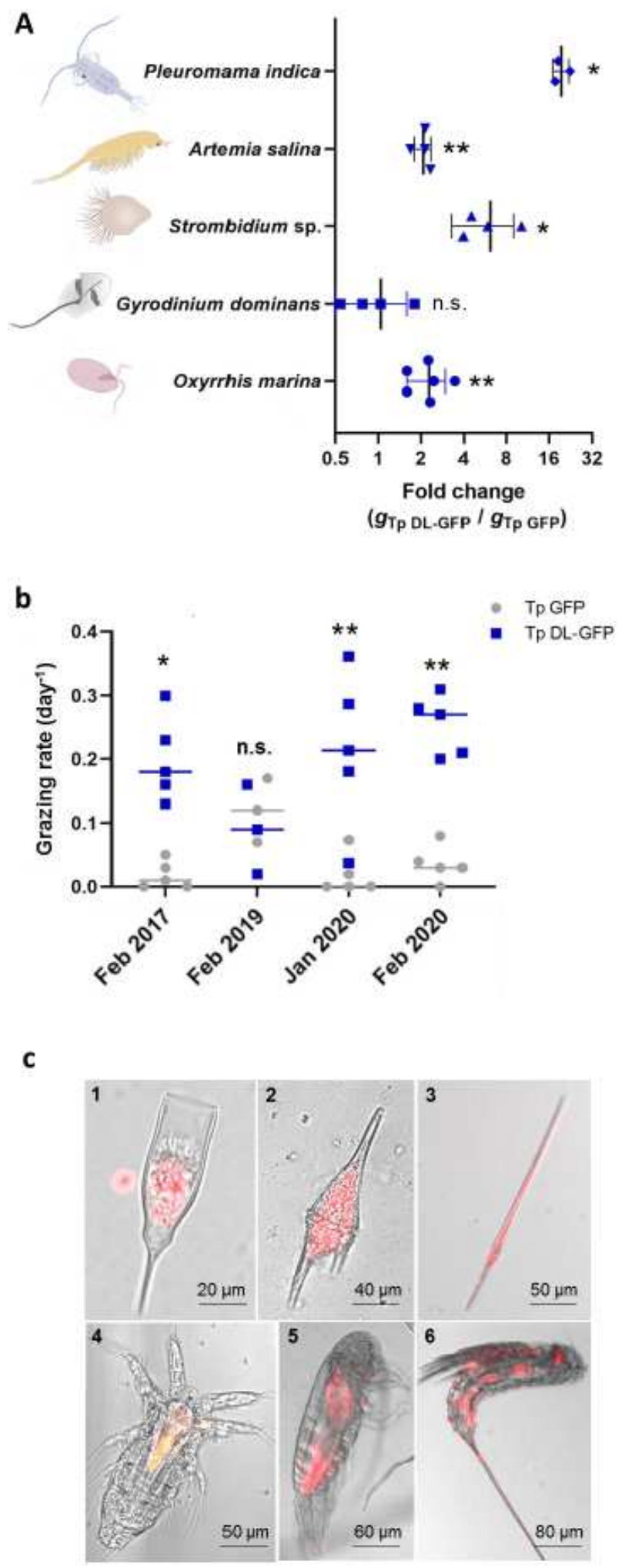

\section{Figure 3}

Induced DMS production in algal prey enhanced grazing by diverse zooplankton. a, The grazing response of diverse zooplankton fed with Tp DL-GFP cells. Tp GFP cells were used as control prey. The fold change in grazing rate ( $\mathrm{g}$, as assessed by monitoring free prey cells using flow cytometry) on each prey type was calculated, where fold change $>1$ indicates faster grazing on Tp DL-GFP cells. Vertical lines represent the mean \pm SD; $n=3$ for P. indica; 4 for A. salina, G. dominans and Strombidium sp.; 6 for O. marina. n.s.- not 
significant, $\mathrm{P}>0.897 ;{ }^{*} \mathrm{P}<0.011 ; * \star \mathrm{P}<0.003$ (one-sample T-test). $\mathrm{b}$, Grazing of Tp DL-GFP cells by natural microzooplankton from the Red Sea. Two prey types were offered to the microzooplankton assemblages: Tp GFP or Tp DL-GFP. Horizontal lines represent the mean; $\mathrm{n}=5-6$. ${ }^{*} \mathrm{P}<0.017$; ${ }^{\star *} \mathrm{P}<0.005$ (Student's Ttest). c, Variety of wild microzooplankton observed during grazing experiments shown in (b), including tintinnid ciliate (1), mixotrophic Ceratium dinoflagellates (2-3) and diverse copepods (4-6). Red represents the chlorophyll of ingested T. pseudonana cells added as prey (mixotrophic dinoflagellates also have endogenous chlorophyll).

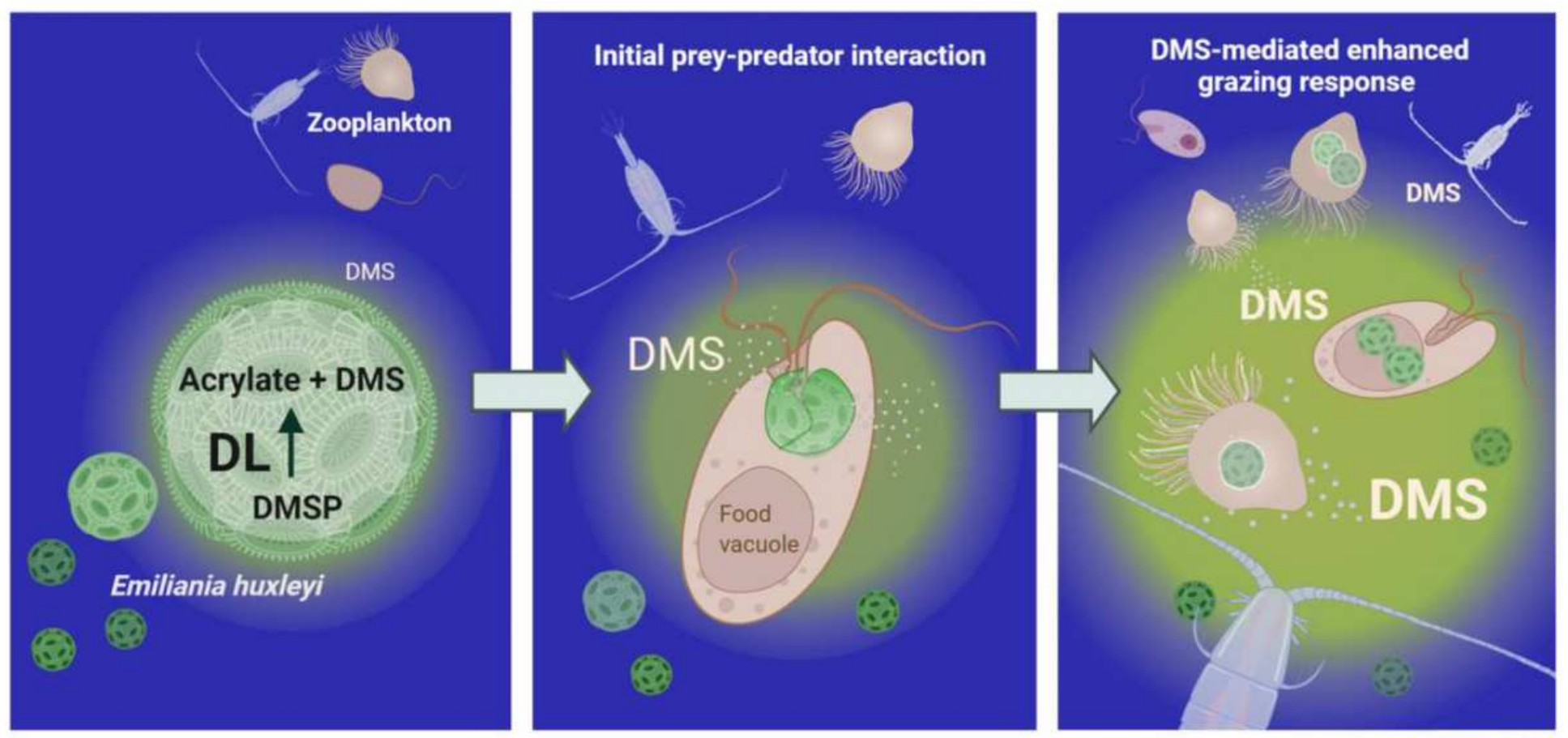

\section{Figure 4}

The ecological impact of algal DMS on planktonic prey-predator interactions. A conceptual model describing DMS-mediated herbivory. Chemoattraction of zooplankton to leakage of DMS from high DMS producing algae such of E. huxleyi cells may facilitate initial grazing interaction (left panel). Upon dissociation of ingested cells during phagocytosis, the DL Alma1 degrades DMSP and releases more DMS into the water (middle panel). This microscale release of DMS may accumulate to high concertation, which induces an increase in the overall grazing pressure by diverse grazers on the entire phytoplankton population (right panel) and thus has wide ecological implication in the marine environment.

\section{Supplementary Files}

This is a list of supplementary files associated with this preprint. Click to download. 
- ShemietalSuppMaterials.pdf 